\title{
CONFLITO DE LEIS EM MERCADOS INTEGRADOS E INTERCONECTADOS: UMA QUESTÃO DE ECONOMIA POLÍTICA
}

\section{Horatia Muir-Watt*}

\section{Um caso de inocência perdida: ${ }^{1}$ modificações na divisão privado/público}

Descrever o direito internacional privado como uma questão de economia política ${ }^{2}$ pode ser visto como uma resposta à modificação tectônica atualmente provocada pela globalização com respeito à divisão do direito público/privado ${ }^{3}$ que modela o pensamento tradicional nesta área. ${ }^{4}$ Uma nova geração de "colisões de regulação econômica" ligada à mobilidade sem precedentes de empresas, produtos, serviços e capital, desafia as concepções continentais européias preponderantes acerca do conflito de leis como uma ferramenta voltada à resolução de disputas puramente privadas. ${ }^{6}$ Não desafiado durante a maior parte do século

\footnotetext{
* Professora na Universidade de Pans I (Pantbéon-Sorbonne). Tradução de Fabio Morosini - Professor na Universidade Federal do Rio Grande do Sul (UFRGS). Tradução livre a partir de Horatia Muir Watt, Cboice of Lan in Intrregated and Interconnected Markeets: A Matter of Political Economy, 9 Columbia Joumal of European Law 383 (2003). A autora gostaria de expressar sua gratidão a Roy Mersky e Jonathan Pratter pela generosa recepção na Tariton Lan Library na Universidade do Texas em Austin durante a preparação deste artigo, e a Christian Joerges pelos seus instigantes comentários sobre uma versão anterior. A inspiração para o título deste artigo vem de um recente artigo escrito por Paul B. Stephan, "The Political Economy of Choice of Law" 90 Geo LJ 957 (2002), que responde ao artigo de Andrew Guzman "Choice of Law: New Foundations," 90 Geo LJ 333 (2002). Um enfoque similar pode ser encontrado num trabalho anterior do mesmo autor, por exemplo, "Choice of Law and Its Consequences: Constitutions for International Transactions," 26 Brook. J. Int'1 L. 211 (2000).

1 A frase é cunhada por Herbert Kronke em sua excelente contribuição "Capital Markets and the Coflict of Laws," Rec Cours Acad La Haye, 378 .

2 Definido, de acordo com Black's Law Dictionary, 7th ed. 1999, como "uma ciência social que lida com os problemas econômicos de governo e a relação entre políticas e processos econômicos."

3 Fora da tradição romana, tal divisão tem sido evidentemente desmantelada mais facilmente. Dentre uma literatura abundante, veja Duncan Kennedy, "The Stages of Decline of the Public/Private Distinction," 130 U. Pa. L. Rev. 1423 (1982); Mary Anne Glendon, "The Sources of Law in a Changing Legal Order," 17 Creighton L. Rev. 663 (1983).

4 A divisão público/privado tem servido um propósito importante dentro da tradição européia continental ao insular o direito internacional privado de interesses políticos. Tal é menos verdade nos Estados Unidos, onde a relação entre direito e política tem sido monitorada pela "cortesia" (comity) na arena internacional, mesmo servindo como uma "ponte" retórica neste contexto (veja Joel R. Paul, "Comity in International Law," 1991 Harv. Intl. L. J. 1), enquanto a agenda federalista têm colorido o direito internacional privado com interesses políticos e públicos. A divisão está, claro, constantemente mudando (veja Horatia Muir Watt, "Droit Public et droit prive dans les rapports internationaux (Vers la Publicisation des conflits de lois)," Arch. Philo. Droit, 207).

5 A expressão foi cunhada por Jurgen Basedow, "Conflicts of Economic Regulation," 1994 Am J Comp L. 423; compare, sobre o mesmo autor neste tema, "Souveraineité territoriale et globalisation dês marches: le domaine d'application des lois contre les restriction de concurrence," 264 Rec Cours Acad La Haye 9 (1997).

6 Lê-se com interesse a seguinte passagem no trabalho de Andreas D. Lowenfeld sobre "International Litigation and the Quest for Reasonableness," Claredon Press, 1996, que oferece excelente material para o pensamento comparativo neste ponto: "I do believe ... that Story was right to think of the conflict of laws as part of the law of nations, and that the term he introduced and that has gained currency in Great Britain and throughout Europe is misunderstood by those who regard private intemational law as sharply distinct from public law or public international law. Thus my definition and approach are very different from those of Batiffol and Lagarde, who define private intemational law as the collection of rules applicable solely to private persons in their international relations." (p. 3).
} 
$\mathrm{XX},{ }^{7}$ o paradigma do interesse privado que constitui o fundamento do conflito de leis não pode mais sustentar a interferência crescente de políticas estatais no campo de contenciosos transnacionais. Obviamente, a teoria jurídica européia tem sido mais relutante do que a doutrina americana em aceitar a idéia de que o direito privado também pode servir como uma ferramenta regulatória, ${ }^{8}$ o que explica a pequena recepção que a análise dos interesses governamentais (governmental interest analysis) recebeu na Europa. ${ }^{9}$ Todavia, como tem sido apontado, áreas como concorrência, securitização, direito bancário, controle de exportação, responsabilidade pelo produto, regulação ambiental, que podem afetar as transações privadas, direta ou indiretamente, envolvem interesses de uma ordem inegavelmente diferente daqueles postulados pela metodologia tradicional do direito internacional privado, ${ }^{10} \mathrm{e}$ introduzem preocupações previamente identificadas como pertencentes ao campo dos interesses públicos e como tais além da estaca do conflito de leis. Na sua expressão mais estrita, este tem sido protegido de preocupações políticas pelo "tabu do direito público" (public law taboo), ${ }^{11}$ o que levou as cortes a declinarem de adjudicar os interesses de outros estados, ao menos quando eles acarretam a execução direta de direitos públicos estrangeiros. ${ }^{12} \mathrm{~A}$ emergência de uma progressiva categoria intermediária de cláusulas intemacionalmente imperativas semi-públicas, ou "lois de police", tem de alguma forma contribuído para romper a lacuna metodológica; enquanto permanece sujeita à metodologia unilateral específica, a regulação econômica estrangeira tem se tornado receptiva para aplicação em cortes nacionais em contenciosos de direito privado.$^{13}$ Fora esta exceção, entretanto, o direito internacional privado lida

7 A idéia de que o direito intemacional privado é uma "receita" para atingir políticas de direito privado foi expressada no trabalho seminal de Franceskakis Théorie du renvoi em 1957 e caracteriza o pensamento dominante até os dias atuais (veja, por exemplo, na França, o prefácio de Grands arrèts de la jurisprudence de droit international prive, por B. Ancel e Y. Lequette, rejeitando como corruptora a instrumentalização do direito internacional privado pelo direito Comunitário europeu ou pela ideologia dos direitos humanos.) Entretanto, mesmo antes deste desafio evidente às teorias do multilateralismo baseadas na soberania, da qual a mais característica encontra-se no trabalho de Etienne Bartin (Principes de droit international privé selon la loi et la jurisprudence française, 3 vol., Paris, 1930, 1932, 1935), o direito internacional privado foi, paradoxalmente, considetado limitado a relaçóes privadas. Tal é claramente um legado do Tratado de Direito Romano (vol VIII) de von Savigny.

8 Que o direito da responsabilidade extracontratual pelo produto, por exemplo, possa ser usado para servir a interesses estatais (por exemplo, ao proteger fornecedores ou vítimas) é tão banal nos Estados Unidos (veja Hay, "Conflict of Laws and State Competition in the Product Liability System," 80 Geo L R 617) quanto é recente na Europa (veja por exemplo, Jane Stapleton, "Three Problems with the New Products Liability," Essays for Patrick Atiyah, Cane and Stapleton, Oxford, 1991, p.291). Mais nova ainda é a idéia de que o direito privado dos contratos possa ser usado para regular mercados, através da proteção do consumidor, por exemplo (veja Hugh Collins, Regulating Contracts, OUP 1999).

9 Uma expressão característica da recusa em aceitar que interesses estatais podem encontrar expressão no direito privado pode ser encontrada em Gerhard Kegel, "The Crisis of the Conflict of Laws," Rec Cours Acad. La Haye, 1964, t. 112, p. 91.

10 Russell J. Weintraub, "The Extraterritorial Application of Antitrust and Securities Laws: Na Inquiry into the Utility of a "Choice of Law' Approach," 70 Tex L R 1799 (1992).

11 Philip J. McConnaughy, "Reviving the 'Public Law Taboo' in International Conflict of Laws" 35 Stan. J. Int'1 L. 255; William S Dodge, "Extraterritoriality and Conflict of Laws Theory: An Argument for Judicial Unilateralism," 39 Harv. Int'l LJ 101

2 F A Mann, "The International Enforcement of Public Rights", publicado traduzido em 77 Rev crit DIP 1 (1988).

13 O estímulo tem sido o artigo 7 inciso 1 da Convenção de Roma, que prevê a aplicação de leis imperativas estrangeiras que suprimem a autonomia da vontade das partes. Um dispositivo parecido está disposto na Convenção de Haia sobre a Lei Aplicável aos Contratos de Mediação e Representação, 1978, artigo 16. Mas estes textos regulam pretensões inicialmente dispostas em contrato, de modo que a interferência de direito público estrangeiro poderia talvez ser considerada como um caso de aplicação incidental (como tanto o Reino Unido e a Alemanha argumentam, ao não optarem (opt out) pelo artigo 7, inciso 1). Sobre esta aplicação incidental de direito público estrangeiro, veja Hans Baade, "The Operation of Foreign Public Law," 30 Tex Int'l LJ 429 (1995). 
exclusivamente com "relações de direito privado;" governos, pensa-se, não se preocupam diretamente com os resultados. ${ }^{14}$ Todavia, depois de perder a sua "neutralidade" nos anos 70 ao permitir considerações seletivas de resultados, ${ }^{15}$ o conflito de leis também parece fadado a perder a "inocência" que um dia serviu para mantê-lo distinto da política intemacional.

\section{O desafio adicional da integração de mercados para a teoria européia do conflito de leis}

Hoje, os Estados Membros da União Européia também estão enfrentando o fato de que uma estrutura política federal ou integrada necessariamente impacta na maneira com a qual os conflitos entre os direitos das unidades componentes são reconhecidos e resolvidos e que a alocação de jurisdição legislativa dentro de tal estrutura de fato acarreta preocupações governamentais. ${ }^{16}$ De fato, enquanto os esforços para aproximar as legislações nacionais podem aparentar reduzir o drama do direito internacional privado, a criação de uma comunidade mais próxima parece, paradoxalmente, concentrar mais atenção em interesses estatais; questões de poder regulatório dentro do mercado interno tornam-se centrais para a função do direito internacional privado, enquanto teorias políticas do conflito de leis parecem fadadas a florescerem. ${ }^{17}$ De um ponto de vista europeu, a novidade paira, não só na nebulosidade da divisão público/ privado e na inadequação do paradigma tradicional do interesse privado para explicar as transformações induzidas por novos interesses quasefederalistas, mas também na necessidade de um sistema de conflito de leis dual, voltado por um lado para lidar com atividades transfronteiriças dentro do mercado interno, e, por outro, para definir o alcance da regulação Comunitária em relação ao direito de terceiros estados. ${ }^{18}$ Esta separação entre conflitos interestaduais e internacionais - ou então, entre conflitos sujeitos à autoridade estatal ou federal ${ }^{19}$ - existe há muito tempo nos Estados Unidos, os

14 Kegel, op cit.

15 A crença largamente aceita na Europa de que os governos não têm um interesse direto nos resultados nos casos de direito internacional privado não significa que os legisladores não demonstram interesse pela implementação de políticas substantivas em direito privado. Tal faz surgir normas altemativas de conflito de leis, assim como aquelas designadas a promover o interesse da criança no âmbito de relacionamentos familiares (por exemplo, os artigos 311-16 a 311-18 do código civil francês).

16 Logo, reconhecimento mútuo e a regra do país originário tendem a enquadrar o conflito de leis como uma questão política, como revela-se aparente do estudo de Juca Snell: Goods and Services in EC Law. A Study of the Relationships Between the Freedoms, Oxford 2002.

17 A ideologia dos direitos fundamentais sem dúvida será um veículo para tal abordagem na Europa. Para um exemplo da maneira pela qual vários direitos impactam no direito internacional privado no âmbito do direito de família, veja $\mathrm{A}$. Bucher, "La famille em droit international prive," 283 Rec Cours Acad La Haye 9-186 (2000). Pode ser, por outro lado, que uma teoria política de direitos negativos, tal como a proposta por Lea Brilmayer ("Rights, Fairness and Choice of Law", 98 Yale LJ 1277, 1989) seja desnecessária na Uniăo Européia, devido às garantias embutidas no direito internacional privado Europeu ou jurisdição judicial para garantir liberdade contra surpresas injustas ou interferências. As liberdades fundamentais e o princípio da proporcionalidade podem servir a um fim similar.

18 Atualmente, este sistema é particularmente complexo pois a tomada de decisões em ambas esferas se dá em múltiplos níveis. Nem todas as normas de conflito de leis dos Estados Membros em áreas que podem afetar o funcionamento do mercado interno estão harmonizadas, e os conflitos com terceiros estados estão sujeitos ao direito Comunitário apenas à medida que este pró́ba não optar pela proteção harmonizada. Veja acerca deste último aspecto, P. Lagarde, «Heurs e malheurs de la protection internationale du consommateur dans l'Union européene ", in Le contrat au début du Xxème siècle, Etudes offertes à Jacques Ghestin, 2000, p. 511

19 Lea Brilmayer, ("The Extraterritotial Application of American Law", 50 Law \& Contemp. Pbs 11) explica que a real distinção entre o Second Restatement on the Conflict of Lans e o Tbird Restatement on Foreign Relations paira na existência ou não de regulação 
primeiros sendo até certo nível constitucionalizados. ${ }^{20}$ Os últimos, formulados em termos de "jurisdição prescritiva" (prescriptive jurisdiction), estão sujeitos a limitações aparentes de direito intemacional público ou cortesia (comity); ${ }^{21}$ eles envolvem definir o alcance internacional da legislação econômica federal, e, quando uma pretensão não está amparada por esta, não deixam espaço para a execução de direito público estrangeiro. ${ }^{22}$

\section{Novas perspectivas: a teoria econômica do conflito de leis numa estrutura de mercado}

Logo, a perspectiva européia sobre o direito internacional privado está sendo reformulada pelas pressões ocasionadas pela globalização e pela integração do mercado interno, as quais ambas, por diferentes razões, desafiam o modelo de direito privado e concentram atenção na importância política de assegurar a alocação apropriada de autoridade regulatória. A tese deste artigo é, muito simplesmente, que uma análise econômica da relação entre o direito e o mercado pode ser usada para esclarecer a função do conflito de leis tanto numa estrutura global quanto de mercado interno e sublinhar algumas das transformações através das quais o novo ambiente econômico e institucional influencia a teoria tradicional. Baseia-se na recente doutrina americana, que tem sugerido que a análise econômica poderia fornecer fundamentos renovados para o conflito de leis, ${ }^{23}$ embora as presentes conclusões possam se diferenciar daquelas em muitos respeitos. ${ }^{24} \mathrm{Em}$ comum com as propostas americanas,

federal. Logo, alguns conflitos internacionais sujeitam-se ao conflito de leis sob o Second Restatement, quando ocorrem em áreas como da responsabilidade extracontratual, que não se sujeita à legislação federal. Por outro lado, quando uma pretensão é embasada em regulação federal, as cortes federais são competentes, e analisam as situações de direito internacional privado, que envolvem determinar o alcance das leis federais, em termos de "jurisdição prescritiva."

$20 \mathrm{O}$ atual estado do direito neste ponto resulta de Allstate Insurance v. Hague, 1981, 101 S.Ct. 633, Phillips Petroleum v. Shutts, 1985, 105 S.Ct. 2965, Sun Oil v. Wortman, 1988 S. Ct. 2117. Debate-se se, de fato, as restrições constitucionais também estendemse para o exercício de jurisdição - ao menos jurisdição judicial - no contexto internacional (veja Brilmayer \& Norchi, "Federal Extraterritoriality and Fifth Amendment Due Process," 105 Harv. LR 1217). Sobre o impacto do federalismo no conflito de leis americano, veja Robert Sedler, "American Federalism, State Sovereignty and the Interest Analysis Approach to Choice of Law," in Law and Justice in a Multistate World, Essays in Honor of Arthur t. von Mehren, 2002.

21 Veja o Third Restatement on Foreign Relations Lam; 1987, Seção 403 e Andreas F. Lowenfeld, International Litigation and the Quest for Reasonableness, 1996, p. 17. Para uma crítica sobre a maneira pela qual a retórica da cortesia intemacional (comity) tem sido usada pelas cortes, algumas vezes como uma ponte entre direito e política e algumas vezes como uma parede, veja de novo Joel R. Paul, "Comity..."

2 De fato, na ausência de uma questão federal, proveniente da aplicabilidade de legislação federal, as cortes federais carecem de competência.

23 Andrew Guzman, "Choice of Law: New Foundations," 90 Geo LJ 883, 2002. Este texto é anunciado como "uma estrutura obrigatória para toda futura doutrina" por Paul B. Stephan, "The Political Economy ..." p. 969. Dentre a literatura prévia e abundante, veja Michael Solimine, "An Economical and Empirical Analysis of Choice of Law”, 24 Ga L R 949, 1989; Erin O'Hara \& Larry Ribstein, "From Politics to Efficiency in the Choice of Law", 67 U Chi L R 1151 (2000); Michael Whincop \& Mary Keyes, "Putting the Private Back into International Law: Default Rules and the Proper Law of Contract", 21 Melbourne U L R 515 (1998); Michael Winchop \& Mary Keyes, "Towards an Economic Theory of Private International Law," 25 Australian Journal of Legal Philosophy 10 (2000); Joel Trachtman, "Conflict of Laws and Accuracy in the Allocation of Government Responsibility," 26 Van J Transnat'1 L 975, 1994; Joel P. Trachtman, "Economic Analysis of Prescriptive Jurisdiction and Choice of Law," 42 Va J Int'l L 1 (2001); veja de uma perspective européia, H. Muir Watt, "Law and Economics': Quel apport pour le droit international privé?", in Le Contrat au début du XXème siècle, Etudes offertes à Jacques Ghestin, 2000, p. 685.

24 Particularmente quando elas parecem encorajar desregulação e "privatização" excessivas do direito internacional privado. Não existe, entretanto, consenso dentro deste novo movimento com relação à extensão com a qual a desregulação e a "privatização" deveriam ser incentivadas. Veja, por um lado, Erin O'Hara \& Larry Ribstein, "From Politics to Efficiency ...", Michael Whincop \& Mary Keyes, "Putting the "Private' back ...", e por outro lado, crítico para com a privatização excessiva, 
entretanto, a presente tese ampara-se na teoria de mercado liberal, segundo a qual o acordo privado é a forma ótima de alocar recursos, na ausência de falhas de mercado ou custos sociais; ao apoderar os indivíduos para agirem em seus próprios interesses, os mercados satisfazem eficientemente as diversas preferências pessoais. ${ }^{25}$ A regulação pública torna-se necessária, por outro lado, na presença de externalidades. ${ }^{26}$ As implicações normativas desta distinção básica para a regulação dos mercados internacionais podem parecer, sob várias formas, como vinho velho em garrafas novas. As transações transfronteiriças despertam o direito internacional privado, ou, em termos mais familiares ao movimento de direito e economia, exigem uma alocação de jurisdição regulatória. ${ }^{27} \mathrm{~A}$ teoria de mercado sustenta que a escolha do direito aplicável pelas partes é a maneira ótima de alocar esta autoridade, ${ }^{28}$ a menos que exista um risco que a escolha das partes e o interesse público não coincidam. Em tal caso, quando as externalidades transfronteiriças ocorrem num contexto internacional, a competição legislativa será suplantada por alguma forma de alocação obrigatória de autoridade decisória. A maioria dos sistemas ocidentais de direito internacional privado projeta este modelo dentro do campo de transações de mercado; estas são geralmente reguladas pela autonomia da vontade das partes, que éentretanto restringida em nome de interesses estatais ou ordem pública. ${ }^{29}$ Logo onde, então, está o novo vinho?

\section{Unilateralismo e bem-estar global}

A mudança não é meramente no vocabulário. ${ }^{30}$ Primeiramente, reformular o conflito de leis em termos de teoria de mercado volta a atenção para questões de bem-estar global levantadas pelo unilateralismo inerente às abordagens atuais à jurisdição prescritiva no contexto internacional..$^{31} \mathrm{Na}$ falta de uma autoridade central, a extensão com a qual as preocupações de interesse público interferem na escolha das partes é deixada à decisão unilateral de cada

Joel P. Trachtman, "Economic Analysis of Prescriptive Jurisdiction ..." Em várias situações, também, a análise econômica aparenta reinventar a roda, através da atenção insuficiente à teoria tradicional do direito internacional privado. Sobre os beneficios que o movimento de direito e economia em conflito de leis possa ganhar da análise comparativa, veja Jan Kropholler \& Jan von Hein, "From Approach to Rule-Orientation in American Tort Conflicts!, in Law and Justice in a Multistate World, Essays in Honor of Arthur T. von Mehren, Transnational, 2002, p. 317. Tal aplica-se, em particiular, à idéia de que o bem-estar dos indivíduos, não a soberania, é a medida correta para o direito internacional privado.

25 Hugh Collins, op cit, p. 70.

26 Ibid. Logo uma divisão tradicional aparece entre as funções de direito privado, que suporta ações voltadas ao interesse próprio, e de direito público, que compele os participantes do mercado a levar os custos sociais em consideração e então protege preferências que não são adequadamente protegidas através do mercado. Entretanto, não apenas os rótulos mudam (o direito privado pode aparecer como uma ferramenta regulatónia), mas incentivos para intemalizar os custos sociais podem ser alcançados através da alocação de direitos sobre a propriedade ou regras de responsabilidade, que são tradicionalmente direito privado. Para uma analogia interessante entre direitos sobre a propriedade e jurisdição regulatória, veja Joel P. Trachtman, "Economic Analysis of Prescriptive Jurisdiction ..."

27 Veja novamente Joel P. Trachtman, "Economic Analysis of Prescriptive Jurisdiction ..."

28 A teoria do mercado vê a própria regulação como um bem público, sujeita à competição interurisdicional. Sobre a teoria da competição interjurisdicional, desenvolvida abaixo no contexto do federalismo econômico, veja abaixo notas de rodapé 38 , 40.

2 Veja por exemplo os artigos 3, 5-6, 7 e 16 da Convenção de Roma sobre Lei Aplicável às Obrigações Contratuais, de 1980.

30 O leitor europeu que se questiona até que ponto os conceitos econômicos são meramente uma mudança no repertório retórico do advogado deve ler Bruce Ackerman, "Law, Economics, and the Problem of Legal Culture," 1986 Duke Law Journal 929

31 Concluindo, semelhantemente, que a análise do conflito de leis em termos de eficiência volta a atenção para preocupações de bem-estar global, veja Paul B. Stephan, "The Political Economy ..." 
estado, que então define independentemente o alcance de sua própria legislação e formula a sua própria concepção acerca da melhor forma de lidar com os custos sociais numa estrutura internacional. Riscos de sub - ou super - regulação são assim endêmicos ao mercado global e certamente não conducentes ao bem-estar geral, que requereria, no mínimo, uma alocação coerente de autoridade regulatória. ${ }^{32}$ Segundo, entender a relação entre o direito e o mercado no contexto de um arcabouço regulatório estruturado, tal como pode ser encontrado numa estrutura integrada ou federal, pode ajudar a sugerir maneiras pelas quais o bem-estar geral possa ser alcançado. Em tal contexto, as externalidades transfronteiriças e as falhas de mercado são tratadas pela autoridade legislativa central, através de regras substantivas harmonizadas. ${ }^{33}$ Enquanto elas tomam a forma de standards mínimos para as transações no mercado interno, elas também são projetadas para o mercado mundial sob a forma de normas internacionalmente imperativas, nos casos em que o legislador europeu decidiu que a conexão com a Comunidade é suficiente para justificar o seu interesse..$^{34} \mathrm{Em}$ ambas as instâncias, elas são elaboradas para fornecer uma estrutura regulatória efetiva dentro da qual a escolha das partes possa operar efetivamente. Entretanto, enquanto a legislação substantiva harmonizada pode obviamente projetar uma visão coerente dos requisitos do bem-estar coletivo dentro do mercado interno, tal não é claramente o caso numa estrutura global. O novo vinho logo reside na idéia de que os conflitos de regulação econômica deveriam se encaixar dentro de uma estrutura maior de regulação de mercado coerente, com um foco claro no bem-estar global. Mais do que uma mudança no vocabulário, isto implica redefinir o alcance e a função do direito internacional privado.

\section{A função dual do conflito de leis no mercado global}

A transformação de perspectiva sublinhada pela análise econômica é evidenciada pela pressão crescente em incluir a regulação pública dentro do alcance do direito internacional privado. Primeiramente, quando desejável, a competição inter-jurisdicional não é tida como sendo restrita a áreas tradicionalmente rotuladas de "direito privado", mas também se estende à regulação de bens públicos ofertados em diferentes locais para empresas e capital móveis. Segundo, na ausência de uma autoridade central ou um acordo internacional para tratar dos efeitos a terceiros, a única maneira - embora não a melhor (second-best $)^{35}$ - para reduzir a

22. As inconsistências que levam a super-regulação são particularmente intoletáveis quạndo cada uma das regulações envolvidas prevê sanções criminais. Veja o dilema no caso Nippon Paper, Dorsey J. Ellis Jr, "Projecting the Long Arm of the Law: Extraterritorial Criminal Enforcement of US Antitrust Laws in the Global Economy," 1 Washington University Global Studies Law Review 477 (2002). Mas evidentemente, as lacunas e sobreposições regulatórias são uma característica bem conhecida das metodologias unilateralistas e monopolistas pelas quais os Estados definem o escopo de suas regulações econômicas.

33 Estas podem dispor sobre a proteção do consumidor/investidor (essencialmente formulada para curar assimetrias de informação, veja abaixo nota de rodapé 49), ou resguardar contra restrições à competição. Sobre o alcance do "direito contratual europeu," que se estende a áreas tal como direito da concorrência geralmente não incluído na categoria de direito privado contratual, veja Stephan Grundmann, “The Structure of European Contract Law," 4 European Review of Private Law," 505-528 (2001).

34 Uma "conexão estreita" com o território de um Estado Membro é geralmente exigida para legislação consumerista (veja P. Lagarde, op cit). $\mathrm{O}$ alcance da direito da concorrência Comunitário é medido por um teste similar ao teste americano dos "efeitos" (veja abaixo, nota de rodapé 124).

35 Há um debate considerável com relação à desejabilidade e factibilidade de um acordo internacional sobre conflitos de regulação econômica (por exemplo sob a égide da OMC): veja Eleonor M. Fox, "Antitrust and regulatory Federalism: Races Up, Down and Sideways," New York Univ. L R 1781 (2000). Também é verdade - e este é o risco inerente a qualquer segunda 
discrepância entre direitos nacionais e mercados globais ${ }^{36}$ seria estender o alcance do direito internacional privado para áreas atualmente portando o rótulo de "direito público", a fím de formular testes apropriados para alocar autoridade regulatória econômica. Aqui, então, está a economia política do conflito de leis numa estrutura de mercado. Fomentar a competição legislativa através da escolha das partes na medida que os custos sociais e os custos privados coincidem (I), o direito internacional privado também deveria ser confiado para assegurar uma função regulatória em casos de externalidades transfronteiriças (II).

\subsection{O conflito de leis como um instrumento de competição interjurisdicional}

\subsubsection{Perspectivas revertidas}

A retórica tradicional do direito internacional privado sugere que o conflito de leis tem uma função mantenedora da paz entre pretensões regulatórias rivais, mutuamente excludentes. Os vários modelos teóricos reforçam esta impressão: o multilateralismo porta uma política de alinhamento a fim de produzir harmonia decisional a partir do caos, ao passo que as teorias neo-estatutárias tendem a perseguir um objetivo de deferência política projetado para induzir a reciprocidade. A análise econômica contemporânea oferece uma perspectiva revertida, na qual a idéia de que a diversidade é uma fonte de desordem a ser eliminada sempre que possível, é suplantada pela convicção que a competição entre legisladores nacionais é basicamente salutar. ${ }^{37}$ Distante de suas justificações tradicionais, a autonomia da vontade em transações transfronteiriças é vista através de lentes econômicas como instrumental para estimular tal competição, num contexto federal, onde ela promove integração de mercado (A), e, mais controversamente, no contexto global, onde ela pode contribuir para a alocação horizontal eficiente de autoridade regulatória (B).

\subsection{O conflito de leis e a economia do federalismo}

\subsubsection{Três novas utilidades para o conflito de leis}

Numa estrutura federal ou verticalmente integrada, a competição interjurisdicional aparece como uma altemativa à regulação centralizada. A temática da competição regulatória, com a questão correlata acerca do nível ótimo ao qual a regulação deveria ocorrer, apenas recentemente começou a aparecer como um assunto para debate na União Européia, ${ }^{38}$ onde é mais comum pensar-se sobre a diversidade jurídica como sendo contrária à idéia de um

melhor opção tal como a proposta neste artigo - que na ausência de acordo, se as cortes tentarem reproduzir o que os acordos internacionais alcançariam, as dinâmicas de dilema do prisioneiro também podem surgir (veja Dodge, Extraterritoriality and Conflict-of-Laws ..."

36 Sobre a discrepância, veja Eleonor Fox, "National Law, Global Markets and Hartford: Eyes Wide Shut," 68 Antitrust L J 73 (2000).

37 Enquanto enfatiza a importância do direito internacional privado, esta perspectiva também reitera o direito comparado como uma fonte de escolha informada.

33 Veja para uma primeira e excelente contribuição, Wolfgang Kerber, "Interjurisdictional Competition within the European Union," in The Regulation of Global Markets, Weimar Symposium 1998, Fordham Intemational Law Joumal 2000.217; A. Ogus, Competition between national legal systems - a contribution of economic analysis to comparative law," 48 ICLQ 405 (1999). Sobre o caráter complexo de múltiplos níveis desta competição, veja Frey \& Eichenberg sobre o conceito de "FOC)" (functional, ovetlapping, competing jurisdictions), in "FOCJ: Competitive Govemments for Europe," 16 Intl Rev L \& Eco 315 (1996). 
mercado interno. ${ }^{39}$ Emprestada da doutrina americana, ${ }^{40}$ a economia do federalismo agora levanta novas questões tanto com relação às formas as quais a autoridade legislativa deveria ser alocada verticalmente dentro da União Européia, enfatizando a importância da subsidiariedade, ${ }^{41} \mathrm{e}$, paradoxalmente, quanto à importância da emulação entre legislações nacionais como um fator de integração. ${ }^{42} \mathrm{O}$ desejo pela desregulação está ligado aos perigos da centralização, que acarretam rent-seeking ${ }^{N T}$ e problemas de public choice ${ }^{N T}$, burocratização excessiva e uma inabilidade de responder às preferências dos indivíduos. ${ }^{43}$ Reduzir o nível em que a regulação opera a fim de introduzir mais pressão do mercado nos legisladores implica reintroduzir o direito internacional privado em áreas que podem ter sido excluídas para unificação. Entretanto, como uma ferramenta econômica do federalismo, o direito internacional privado tem que se encaixar num esquema sofisticado, de múltiplos níveis, que afeta a sua função tradicional de várias formas. Primeiramente, ao manter um ambiente de livre competição regulatória entre direitos nacionais, o direito internacional privado torna-se um importante instrumento na alocação vertical de competências dentro da União (a). Segundo, sob a pressão da integração de mercado, o direito internacional privado simultaneamente promove as liberdades fundamentais de mercado (b). Finalmente, estendendo o seu alcance ao mercado de bens públicos, o direito internacional privado tem que assegurar que a competição entre as políticas econômicas nacionais permaneça livre de distorções (c).

\subsubsection{Estabelecer a alocação vertical de competências}

$O$ direito europeu dos contratos ${ }^{44}$ fundamenta-se na distinção entre regulação harmonizada centralmente, projetada para curar as falhas de mercado, ${ }^{45}$ por um lado, e

39 De fato, até recentemente, uma forte tendência em favor da centralizaçăo da autoridade regulatória dentro da Europa tendia a tornar a diversidade suspeita; a integração parecia implicar harmonização no nível mais elevado, e a conseqüente "morte" do direito internacional privado e do direito comparado (veja, respectivamente ao último, Ch. Von Bar, "From Principles to Codification: Prospects for European Private Law," 8 Colum J Eur L 379 (2002); Simpósio sobre Metodologia e Epistemologia do Direito Comparado, Bnixelas, Outubro 2002, a ser publicado pela Hart Publishing)

$40 \mathrm{O}$ volume de literatura sobre esta matéria é impressionante. Veja, em especial, a edição especial do Journal of International Economic Law (2000), devotado à "Regulatory Competition in Focus," com contribuições de Daniel C. Esty, Richard L. Revesz, Damien Gerardin, Jonathan R. Macey, Alan O. Sykes, Joel P. Trachtman, relativos a uma vasta gama de distintas áreas. Veja também, Ulen, "Economic and Public Choice Forces in Federalism," 6 Geo Mason L Ver 921; Frank H. Easterbrook, Federalism and European Business Law," 14 Int'l Rev. L. \& Econ. 125.

41 Os linkes entre subsidiariedade e competição regulatória em vários níveis também dão origem a uma literatura abundante. Veja, por exemplo, R. Van den Bergh, "Subsidiarity as na Economic demarcation principle and the Emergence of European Private Law, "5 Maastricht Journal 129 (1988); George Bermann, "European Community law from a US Perspective," 4 Tul J Int'1 \& Comp. L 5 (1995); Christian Kirchmer, "The Principle of Subsidiarity in the Treaty on European Union: A Critique from the Perspective of Constitutional Economics," Tul J Int'l \& Comp. L 291 (1998), Breton, Cassone \& Fraschini, "Decentralization and Subsidiatity: Toward a Theoretical Reconciliation," 19 U Pa J Int'l Econ L 21 (1998).

42 Veja Kerber, Van den Bergh, sobre a competição como um processo de aprendizagem e suas contribuições à integração. NT Rent-seeking refere-se às tentativas de se obter rendimentos econòmicos (por exemplo, pagamento para o uso de um bem econômico em excesso ao valor de mercado) através de intervenção estatal no mercado.

NT Public Cboice é sinônimo de utilização de premissas e metodologias econômicas na ciência política.

43 Kerber, p. 218.

44 Esta distinção é central à Convenção de Roma sobre a Lei Aplicável às Obrigações Contratuais, de 1980, onde aparece no artigo 3 (liberdade de escolha) e no artigo 5 a 7 (regras imperativas intemacionais).

45 A regulação de falhas de mercado é projetada essencialmente para remediar assimetrias informacionais, através de regras imperativas de diclosure (sobre a prioridade dada pela Corte Européia de Justiça como na sua decisão do caso Cassis de Dijon 
normas nacionais facilitadoras de escolha (choice-facilitating rules) ${ }^{46}$ que permanecem receptivas ao direito internacional privado, e em particular à autonomia da vontade livre, por outro lado. ${ }^{47}$ A autonomia da vontade logo opera dentro de uma estrutura regulatória centralizada que cura as assimetrias de informação e as restrições à competição. ${ }^{48}$ Entretanto, assegurar o efeito transfronteiriço completo da autonomia da vontade ${ }^{49}$ também exige a remoção de barreiras regulatórias nacionais que interferem no acesso aos mercados nacionais. A regulação das falhas de mercado multiplica-se como uma questão de integração de mercado. ${ }^{50} \mathrm{O}$ direito Comunitário portanto impõe uma segunda série de restrições aos Estados Membros, similar àquelas resultantes dentro dos Estados Unidos da Cláusula de Comércio "dormente", segundo a qual os Estados devem abster-se de aplicar medidas que levarão à super-regulação ou múltiplos ônus restringindo acesso a outros mercados europeus. O escrutínio de acordo com as liberdades de mercado pode aplicar-se a qualquer forma de regulação imperativa de um Estado, que é internacionalmente executável na forma dos artigos 5 a $7 \mathrm{da}$ Convenção de Roma, inclusive medidas implementando diretivas Comunitárias, ${ }^{51}$ mas não aplica-se às normas facilitadoras de escolha abrangidas pelo artigo 3 da Convenção de Roma. Logo, a norma de direito internacional privado reguladora das transações dentro do mercado interno fixa uma linha divisória dupla: ela demarca a regulação internacionalmente imperativa a partir do alcance da autonomia da vontade, enquanto simultaneamente assegura a alocação vertical de competências entre o direito Comunitário, impondo standards mínimos (proteção do consumidor) ou máximos (liberdades de mercado), e regulação em instância inferior, em nível de Estado Membro, da grande variedade do direito contratual. Se a linha divisora admitidamente carece de clareza em alguns casos, pode ser devido a flutuações na jurisprudência da Corte Européia de Justiça com relação à extensão desejável de competição regulatória. ${ }^{52}$

em 1979, a disclosure imperativa sobre proteção substantiva, veja Grundmann, p. 513). As falhas de mercado também são endereçadas através de regras Comunitárias contra restrição de competição, presente no artigo 7. Falhas do estado, ao contrário de colapso do mercado, é remediada através da subsidiariedade.

46 Estas são essencialmente normas de direito contratual clássico relativas à formação e execução do contrato, e estipuladas para ajudar as partes a exercerem sua liberdade de mercado.

47 As normas nacionais desta categoria não sujeitam-se ao escrutínio das liberdades fundamentais: Corte Européia de Justiça, Alsthom Atlantique, 24 Jan $1991, \mathrm{C}-339 / 89$

48 Legislação protetiva aplicável aos contratos de consumo transfronteiriços ou transações internacionais de securitização, tal como aquelas adotadas pela legislação secundária da Comunidade Européia, são planejadas para erradicar as assimetrias de informação, que podem caso contrário levar à escolha viciada - inclusive escolha da lei aplicável. Sobre o enfoque do direito Comunitário na disclosure ao invés de normas substantivas de proteção do consumidor (obigatórias no tocante a medidas nacionais pela Corte de Justiça em Cassis de Dijon e até onde concerne o legislador Comunitário pelas liberdades fundamentais e proporcionalidade), veja Stefan Grundmann, "The Structure of European Contract Law," 4 European Review of Private Law 505-528 (2001). Sobre desenvolvimentos semelhantes no campo da regulação de securitização, veja Niamb Moloney, EC Securities Regulation, Oxford EC Law Library, 2002.

44 Esta é a função primária das liberdades do mercado interno sob o Tratado da União Européia: veja Grundmann, p. 510.

50 Sobre o fato de que a questão da integração algumas vezes sobrepõem-se às políticas substantivas, em especial à proteção do investidor no âmbito da regulação de securitização, veja Niamh Moloney, op cit.

51 Veja por exemplo, CJCE C-369/96 \& C-376/96, 23 de novembro de 1999, Arblade; 15 de março de 2001, Mazzoleni, estendendo o escrutínio para normas intemacionalmente imperativas do Estado hospedeiro prevendo salário mínimo; veja também, abaixo, sob (b). As medidas escrutinadas podem incluir no rmas não vistas tradicionalmente como direito contratual, inclusive normas de direito público: veja Grundmann, p. 515.

52 Veja Jukka Snell, op cit. Ao implementer as liberdades econômicas, a Corte de Justiça parece hesitar entre um modelo que fomenta a competição de estados, e um modelo mais centralizado, em que o escrutínio das Comunidades Européias passa dos 
Entretanto, o encontro entre a dinâmica econômica do direito Comunitário e as preocupações mais tradicionais do direito privado inevitavelmente trazem modificações às categorias tradicionais, que pode também requerer tempo para acomodar-se. ${ }^{53}$ Logo, o direito preemptivo das liberdades de mercado não é necessariamente intemacionalmente imperativo de acordo com o significado tradicional do artigo 7 da Convenção de Roma, porquanto a regulação econômica pública nacional pode semelhantemente ser desqualificada como tal e sujeita à autonomia da vontade. ${ }^{54}$

\subsubsection{Assegurar a extensão completa das liberdades econômicas}

De fato, a harmonização da legislação dos Estados Membros projetada para remediar as falhas de mercado não precluem a competição inteiramente, pois os legisladores nacionais estão freqüentemente livres para adotarem medidas mais restritivas do que aquelas exigidas pelas diretivas Comunitárias. ${ }^{55}$ Aqui, entretanto, a aplicação de medidas nacionais mais rigorosas para situações transfronteiriças justifica o escrutínio das liberdades fundamentais, a fim de se evitar a reconstituição de barreiras regulatórias. Tal escrutínio tem acarretado à bem-conhecida distribuição de autoridade regulatória dos Estados Membros sob Keck ${ }^{\mathrm{NT}} \mathrm{e}$ sua progenitura, na forma de reconhecimento mútuo. $O$ país de origem pode aplicar a sua regulação em relação ao próprio produto, ao passo que o direito do pás destinatário prevalece no tocante aos arranjos comerciais concernentes. ${ }^{56}$ Uma divisão semelhante pode ser encontrada, por exemplo, na área de serviços financeiros, onde o país destinatário pode impor normas de conduta, enquanto o serviço em si é moldado de acordo com as exigências de prudência e supervisão do país de origem. ${ }^{57}$ Interessantemente, tal configuração acarreta

limites em casos em que não há intenção ou efeito protecionista, sobrepondo-se ao conflito de leis e restringindo a autonomia da vontade. Logo, o caso Bosman de 1995 implementa uma leitura muito expansiva do Tratado, baseada na idéia de acesso ao mercado, em que, praticamente, a mera existência de um conflito de leis parece invocar a competência das Comunidades Européias. Sobre a extensão a qual pode ser necessário distinguir entre as diferentes liberdades: veja Jukka Snell, op cit.

53 Sobre essas mudanças, veja Hans Ulrich Jessurun d'Oliveira, "The EU and a Metamorphosis of Private International Law," in Reform and Development of Private International Law, Essays in Honor of Sir Peter North, Oxford, 2002, p. 111

54 A alocação de competência regulatória entre o estado de origem e o estado destinatário em áreas sujeitas ao escrutínio sob as liberdades fundamentais interessa pontos de direitos público e privado; uma dada determinação do direito aplicável pode ser preterida sob o princípio do pás de origem se o direito aplicável acarretar múltiplos ônus para o importador, por exemplo, se o direito indicado é tecnicamente uma norma imperativa nacional de acordo com o artigo 7 . Ademais, sob o princípio do país de origem, segundo o qual consumidores nacionais beneficiam-se de produtos e serviços moldados de acordo com regulação estrangeira, medidas nacionais reforçando as exigências mínimas de diretivas perdem seu caráter imperativo, dado que aqueles consumidores sempre poderão escapar do alcance da regulação nacional se eles preferirem uma oferta estrangeira. Ao mesmo tempo, a competição regulatória entre estados pode bem estender-se para os bens públicos.

55 Isto está longe de ser verdade em todos os casos, entretanto, particularmente no que concerne regras de informação: veja, por exemplo, a Diretiva de Investimento em Serviços de 1993, ou a nova Diretiva sobre a Venda á Distância de Serviços Financeiros de 2002. A recente jurisprudência da Corte Européia de Justiça decidiu que a proteção do consumidor prevista da Diretiva sobre Responsabilidade sobre o Produto de 1985 não poderia ser melhorada por legislação nacional (aqui, francesa e grega) (veja CEJ 25 de abril 2002, caso C-154/00 e caso C-52/00).

NT Tribunal de Grande Instance de Strasbourg (França), 24 de novembro de 1993, Coletânea da Jurisprudência 1993, p. I-06097. Disponivel em http:/ eur-lex.europa.eu/LexUriServ/LexUriServ.do?uri=CELEX:61991J0267:PT:HTML

56 Veja Jukka Snell, op cit.

57 Uma abordagem alternativa está presente na nova Diretiva sobre a Venda á Distância de Serviços Financeiros de 2002 e na Diretiva sobre Comércio Eletrônico de 2000. Esta última prevê a aplicação da lei do local onde o serviço é prestado e aloca autoridade e jurisdição para assegurar cumprimento das leis do Estado Membro do provedor. Entretanto, a Diretiva indica que ela não prevê regras de direito intemacional privado. Sobre esta ambigüidade, veja Michael Wildespin \& Xavier Lewis, "Lês 
a formulação de uma nova geração de normas de conflito de leis, que levantam questões familiares de qualificação e definição de elementos de conexão. ${ }^{58}$ Projetadas para prevenir discriminação sob a forma de um ônus regulatório duplo imposto nos produtos e serviços que entram num mercado estrangeiro, as novas normas prevalecem sobre as soluções nacionais divergentes de direito internacional privado, e aplicam-se a qualquer que seja a natureza das medidas envolvidas (públicas/privadas; imperativas/à revelia). ${ }^{59}$ Os produtos e serviços podem então entrar no mercado estrangeiro livremente, sem serem privados de suas vantagens competitivas. Ao mesmo tempo, as preferências do cidadão são mantidas porquanto os estados destinatários têm liberdade para procurar pelos arranjos comerciais mais eficientes. Aqui novamente, as modificações nas categorias tradicionais tomam-se aparentes: ao exercer poderes de supervisão, ${ }^{60}$ por exemplo para determinar se a regulação do país de origem se encaixou dentro dos limites estabelecidos por Keck, as-autoridades do país destinatário inevitavelmente analisam o direito público estrangeiro. ${ }^{61}$ Dito de outra forma, o direito internacional privado só pode assegurar a expressão completa das liberdades econômicas dentro do mercado interno ao estender seu alcance ao direito público.

\subsubsection{Fomentar a competição por bens públicos livre de distorções ${ }^{62}$}

A conclusão do mercado interno e o progresso tecnológico claramente conduziram à crescente mobilidade de empresas, ${ }^{63}$ acentuando a competição intra-Européia e melhorando a eficiência alocacional. ${ }^{64}$ Em tal contexto, torna-se claro que a atratividade de uma dada localidade, em termos de preocupações ambientais, qualidade da mão de obra, infra-estrutura, etc, também depende das políticas econômicas de dos Estados Membros. ${ }^{65} \mathrm{~A}$ única forma de limitar tal competição seria centralizar as políticas econômicas ou elevar barreiras à mobilidade. Já foi demonstrado muito convincentemente que os efeitos combinados da desregulação e da mobilidade acarreta competição entre Estados Membros para atração de empresas na área de bens públicos. ${ }^{66}$ De fato, uma importante parte da integração européia

relations entre lê droit communautaire et les règles de conflit de lois " Rev crit DIP 2002.1, p. 299 ; Corcoran \& Hart, "The regulation of Cross-Border Financial Services in the EU Internal Market " 8 Colum J Eur L 221, 246 ; M Fallon \& J. Meesen, " Le commerce électronique, la directive 2000/31/EC et le droit international privé, « Rev crit DIP 2002.465, p. 484.

53 Como em casos mais tradicionais, estes não são sem dificuldade, e requerem reflexão acerca dos objetivos específicos da divisão de competências regulatórias (sobre as duas possibilidades de leituras do Tratado sobre este ponto, uma, decentralizada e antiprotecionista, a outra mais intrusiva da "Giberdade econômica", veja Jukka Senll, op cit.) Por exemplo, o caso Alpine Investment de 1995 (C-384/93, ECR I-1141) demonstra que a própria noção de "arranjos de venda" como distinta das nomas do produto pode ser difícil de definir; foi então proposto de sub-distinguir entre "arranjos de venda" estático e dinâmico (veja Jukka Snell, op cit., p. 94). Para um exemplo interessante diferente da formulação de uma norma de direito intemacional privado relacionada a takeovers, em leilões tranfronteiriços, veja Moloney, op cit., p. 836

59 Sobre estas controversas normas de conflito "ocultas", veja dentre uma abundante literatura, o recente estudo por Michael Wildespin \& Xavier Lewis, op cit.

60 A jurisprudência concemente à extensão desses poderes de supervisão demonstra que os "olhos estão no prêmio" e que o resultado está longe de ser indiferente aos estados. Veja Snell, op cit.

6. Sobre este ponto, veja Snell, op cit.

Q Para uma contribuição completa, veja Kerber, op cit.

(3) O caso Centros da Corte Européia de Justiça (caso C-212/97, Rec. 1999, 1-1459, concl La Pergola) também, até uma determinada extensão, remediou o problema do alto custo da mobilidade de empresas dentro da União Européia.

64 Definida como a alocação eficiente de recursos como fatores de produção posicionados no local de mais alta produtividade.

$\omega$ Kerber, op cit.

66 Ibid. 
parece ser atribuída a antigos estados monopolistas que são transformados em localidades que devem competir com outras por produtos e serviços. ${ }^{67}$ Esta competição regulatória por bens públicos cria incentivos para melhorar o desempenho e assegura que a iniciativa govemamental realmente responda às preferências dos cidadãos. Uma dificuldade importante surge, entretanto, quando o "campo do jogo" (playing field) formado por políticas econômicas divergentes não está nivelado, e a competição entre os Estados Membros pode logo ser vista como distorcida; ${ }^{68}$ claramente as normas de direito público podem criar vantagens competitivas que não se sujeitam ao direito concorrencial entre empresas. Entretanto, os efeitos de um "campo de jogo" desnivelado sobre a competição podem ser facilmente corrigidos ao permitir a livre escolha das empresas com relação às disposições de direito público. ${ }^{69}$ Até então, foi demonstrado que a regra do país de origem (bome-country rule), que presentemente garante a escolha do consumidor por produtos e serviços produzidos de acordo com direitos estrangeiros, não é necessariamente ótima, à medida que ela não assegura a competição regulatória livre de distorções a menos que ela permita a escolha pelos produtores. ${ }^{70} \mathrm{O}$ direito internacional privado, expandindo o seu alcance além do campo tradicional do direito privado, portanto tem uma importante função corretiva ou niveladora a exercer aqui, a fim de assegurar que a competição entre estados por bens públicos permaneça livre de distorções. Logo, formulado dentro de uma estrutura de exigências imperativas que protejam de falhas de mercado, o conflito de leis aparece como uma importante ferramenta desregulatória no mercado integrado. A questão é se um uso similar da competição inter-jurisdicional é sustentável num contexto global, onde inexiste uma autoridade centralizada para monitorar as externalidades ou remediar falhas de mercado através de exigências mínimas.

\subsection{Reciprocidade Portátil”' num Mercado Global? ${ }^{71}$}

\subsection{1 "Apoderando Investidores"? ${ }^{\text {" }}$ ou corrida para o fundo?}

A doutrina americana recente levantou a questão da autonomia da vontade no campo do direito econômico, tal como no mercado de capitais. ${ }^{73}$ A extensão a qual tal competição é

67 Ibid.

\& O Tratado proíbe ajudas financeiras, mas a questão aqui é vantagens ocultas que não podem ser eliminadas sem a centralização das políticas econômicas dos Estados Membros.

(7) Kerber, op cit.

7 Como Wolfgang Kerber explica, ibid, p. 241, atualmente, o princípio do pás de origem acarreta uma distorção. Os Estados deverm permitir a escolha do consumidor de acordo com o princípio do país de origem em casos de vendas ou prestação de serviços transfronteiriços. Logo, os consumidores sempre dispõem da escolha entre diferentes regulações, já que os produtores estrangeiros podem oferecer produtos segundo a regulação do país de origem. Estas regulações são destinadas para a proteção dos consumidores. Elas perdem o seu caráter imperativo sob a regra do país de origem, precisamente porque os consumidores podem escolher produtos produzidos em outro lugar sob regulações diferentes, e se tornarem meros standands. Entretanto, os produtores nacionais não têm uma escolha semelhante de regulações, e permaneceram regulados pelas regras nacionais. $O$ reconhecimento mútuo então acarreta o risco que as regulações nacionais de proteção do consumidor na verdade subsidiam os produtores nacionais. Esta conseqüência poderia ser evitada se os produtores pudessem escolher entre diferentes regulações nacionais, por exemplo, as empresas francesas poderiam produzir de acordo com os standards italianos sem necessitarem se relocar para a Itália.

71 Esta frase foi cunhada por Stephen J. Choi e Andrew T. Guzman, "Portable Recognition: Rethinking the International Reach of Securities Regulation," 71 S Cal L Rev 903 (1998).

72 Esta frase foi cunhada por Roberta Romano, "Empowering Investors: A Market Approach to Securities Regulation", 107 Yale L) 2359 (1998)

73 Choi \& Guzman, Romano, ibid; Stephen J. Choi, "Selective Disclosures in the Public Capital Markets," 35 UC Davis LR 533. 
desejável permanece controversa, entretanto. A competição regulatória realmente "apodera os investidores" ou ocasiona extemalidades prejudiciais com as quais o mercado em si não consegue lidar de forma satisfatória ${ }^{74}$ Apesar do caráter sedutor da tese da competição global, a desejabilidade de confrar as falhas de mercado à autonomia da vontade não está inteiramente clara (a). Isto não significa, entretanto, que a autonomia da vontade não tem lugar na regulação econômica. É provável que o rótulo do direito público, acenando respostas regulatórias às externalidades, seja super-inclusivo (b).

\subsubsection{O argumento controverso pela diferenciação regulatória eficiente}

A idéia de introduzir a competição regulatória em áreas de regulação econômica, ao menos num contexto interestadual, não é nova nos Estados Unidos. ${ }^{75}$ Entretanto, uma segunda geração de debates surgiu recentemente a partir de descobertas empíricas no campo do direito societário, segundo as quais o "efeito Delaware" não significa necessariamente uma corrida ao fundo degenerativa envolvendo o sacrificio dos interesses dos acionistas, mas pode levar à maior sofisticação da oferta legislativa. ${ }^{76}$ Dentro da União Européia, a recente decisão Centros chamou a atenção para um debate parecido. ${ }^{77}$ Significativamente, o cavalo-de-batalha da competição global foi esporado neste e em outros campos pelos juristas do direito e economia (law \& economics), cujas agendas estão voltadas a "pôr o 'privado' de volta ao direito internacional" através da autonomia da vontade. ${ }^{78}$ Logo, sugere-se que a competição regulatória como saída (exit) (ou opção das partes por um direito estrangeiro) poderia ser a forma ótima de governança global em tais áreas como securitização, antitruste, insolvência, bancos ou proteção ambiental..$^{79} \mathrm{O}$ argumento foi mais fortemente avançado na área de securitização, em favor de um sistema de "reciprocidade portátil" 80 envolvendo a livre escolha do direito pelo emissor, logo desconectando o regime regulatório aplicável e a localidade onde a transações das securitização ocorreram. ${ }^{81}$ Argumenta-se que devido à existência um arranjo considerável de diversas preferências entre investidores e emissores, maior competição

74 Merrit B. Fox, "Retaining Mandatory Securities Disclosure: Why Issuer Choice Is Not Investor Empowerment," 85 Va L R (1999); Securities Disclosure in a Globalizing Market: Who Should Regulate Whom?", 95 Mich L R 2498 (1998).

T5 Veja Merrit B. Fox, op cit., p. 1339, sobre o caloroso debate que se desencadeou na metade dos anos 60 sobre a desejabilidade de se deixar a regulação dos níveis de disclosure para as forças do mercado. Um "consenso turbulento" pareceu então emergir, inclusive entre juristas com orientação econômica tal como os Professores Easterbrook, Coffee e Fischel, que a disclosure imperativa deveria ser mantida.

76 Roberta Romano, op cit., nota de rodapé 64.

77 Caso C-212/97, Rec 1999, I-1459, concl La Pergola. Veja Holst, "European Company Law After Centros: Is EU on the Road to Delaware?", compare com Ebke, "Centros - Some Realities and Some Mysteries," 48 Am J Comp L 623; veja também para uma perspective anglo-americana sobre a corrida ao fundo, Robert R. Drury, "The Registration and Recognition of Foreign Corporations: Responses to the 'Delaware' Syndrome," 57 Cambridge Law Journal 165.

78 Whincop \& Keyes, "Putting the 'Private' Back ..."

To No campo de insolvência, veja Ramussen, "Debtor's Choice: A Menu Approach to Corporate Bankruptcy," 71 Tex L Ver 51; antitruste, veja Frank H Easterbrook, "Antitrust and the Economics of Federalism," $26 \mathrm{~J} \mathrm{~L} \mathrm{\&} \mathrm{Econ} 23$ (1983); bancos, Henry N. Butler \& Jonathan R Macey, "The Myth of Competition in the Dual Banking System," 73 Cornell L R 677 (1988). Sobre o impacto da competição regulatória sobre a arbitragem, veja Y. Delazay, "Between the State, the Law and the Market"; in W. Bratton et al., International Regulatory Competition and Coordination, Oxford, Claredon Press, 1996

80 Joel P. Trachtman usa o termo "reciprocidade sem raiz", em "Regulatory Competition and Regulatory Jurisdiction", 2000 Journal of International Economic Law 331-348, p. 344

81 Choi \& Guzman, op cit. 
levará à diferenciação mais eficiente de regimes regulatórios em nível de mercado global, cada um atendendo a diferentes necessidades. Por exemplo, emissores de alta qualidade optarão por fortes disposições antifraude e disclosure e atrairão investidores avessos a riscos. Outros emissores podem preferir um regime protetivo mais fraco, menos custoso, capaz de arrecadar capital barato rapidamente, e os investidores descontarão a diferença no preço. O controle (management) adequar-se-á entre diferentes categorias de acordo com o tipo de regime escolhido, que funcionará como uma forma de marca (brand) alertando os acionistas para possíveis problemas de representação $\left(\right.$ agency) ${ }^{82} \mathrm{Um}$ tal regime apresenta-se como uma alternativa mais eficiente ao alcance super-extensivo da regulação de securitização na atual prática das cortes americanas, que não consegue maximizar os lucros da competição e incentiva os emissores a evitar o mercado americano, em função do conteúdo notoriamente rigoroso da legislação federal. ${ }^{83} \mathrm{Tal}$ tese é indiscutivelmente sedutora e aparenta tornar-se influente na Europa ${ }^{84} \mathrm{O}$ argumento em favor da competição regulatória pura permanece altamente controverso, entretanto. Enquanto o próprio conceito de uma corrida ao fundo tenha sido questionado como uma falácia intelectual ${ }^{85}$ ao mesmo tempo, a autonomia da vontade parece não responder adequadamente à dupla questão de mercado e custos sociais em nível global. Sob o modelo de Tiebout de competição por bens públicos ${ }^{86}{ }^{86}$ que inspira as teorias contemporâneas sobre o federalismo regulatório, os pré-requisitos para a competição locacional livre de distorções são a escolha informada e a ausência de externalidades. Os críticos permanecem céticos se o primeiro pré-requisito pode ser atingido, ${ }^{87}$ mas concentrạm-se mais particularmente no perigo da pressão prejudicial sobre os legisladores nacionais para eliminarem standards elevados a fim de atrair empresas, assim externalizando os efeitos nocivos através da sub-regulação. A área da proteção ambiental oferece clara demonstração empírica que a competição desenfreada leva à regulação sub-ótima sempre que houver externalidades transfronteiriças importantes, ${ }^{88} \mathrm{e}$ demonstrações semelhantes têm sido feitas em tais áreas como bancos ${ }^{89}$ antitruste ${ }^{90}$ ou arbitragem. ${ }^{91} \mathrm{Na}$ melhor das hipóteses, tal demonstração pode indicar que é irreal generalizar, e que os benefícios a serem ganhos da competição regulatória são específicos por áreas. ${ }^{92}$ Entretanto, até mesmo na área de regulação

82 Para um exemplo semelhante da interessante "função de marca" do direito internacional privado, veja Snell, op cit., p. 43, explicando o caso Centros da CEJ desta maneira.

83 Veja Stephen J Choi e Andrew Guzman, "The Dangerous Extraterritoriality of American Securities Laws," 17 Nw J Int'l L \& Bus 207 (1996)

84 Veja Moloney, op cit. p. 12, nota de rodapé 28, referindo-se diretamente à tese desregulatória de Choi \& Guzman.

85 Joel Paul, "Free Trade, Regulatory Competition and the Autonomous Market Fallacy," 1 Colum. J. Eur. Law 29 (1995), demonstrando que o direito e o Mercado não podem ser autônomos

86 Charles M. Tiebout, "A Pure Theory of Local Expenditures", 64 J Pol Econ 416 (1956)

87 Apesar de tentativas admitidamente convincentes para atenuar o problema de excesso de informação ou de "potencial Torre de Babel" que a escolha de lei aplicável ilimitada pareceria desencadear (veja Choi \& Guzman, p. 924)

8 Veja Richard L. Revesz, "Federalism and Regulation: Extrapolating from the Analysis of Environmental Regulation in the United States," 2000 Journal of Int'1 Econ Law 219-233.

8) Butler \& Macey, "The Myth ..."

90 Eleonor M. Fox, "Antitrust and Regulatory Competition ..."

1 Para provas desta competição, W. Michael Reisman, resenha de livro, 80 Am JIL 268.

92 Alcançando esta conclusão, Daniel C. Esty, "Regulatory Competition in Focus," 2000 Journal of Int'l Econ. Law 215-217. 
de securitização, onde os efeitos a terceiros são quiçá menos importantes, ${ }^{93}$ não está claro se a autonomia da vontade pura seria viável ou necessariamente traria resultados desejáveis. Mesmo deixando de lado o problema das escolhas viciadas devido a falhas de informação, tem-se apontado que os benefícios da competição poderiam ser colhidos somente se todos os legisladores estivessem prontos para estender reconhecimento ao regime escolhido; se o reconhecimento não for universal, então as dinâmicas de dilema do prisioneiro entrariam em questão. ${ }^{94}$ Entretanto, a reciprocidade universal é altamente improvável, uma vez que a autonomia da vontade não será permitida por um regulador a menos que o escopo da regulação de securitização seja de fato a proteção dos interesses privados e não do mercado em si. Embora tal seja provavelmente o caso nos Estados Unidos, ${ }^{95}$ a legislação européia parece ter uma preocupação mais forte pela proteção do investidor, ${ }^{96}$ e a autonomia da vontade é vista como sendo desatenta a efeitos sobre terceiros. ${ }^{97}$ A mesma observação pode obviamente ser feita no campo de antitruste e insolvência. Demonstrações semelhantes dos vários focos da regulação econômica e suas conseqüências sobre a desejabilidade de livre competição legislativa tornam-se mais vigorosas ainda com relação às políticas de países em desenvolvimento, onde a regulação antitruste pode ser projetada para "aumentar a competição" ${ }^{\prime 98}$ e onde preocupações ambientais podem conflitar com necessidades econômicas mais básicas. ${ }^{99}$

\subsubsection{A necessidade por equilíbrio: o rótulo atual do direito público é superinclusivo}

Seria excessivo concluir, entretanto, que a competição regulatória através da autonomia da vontade não tem lugar no mercado global. De fato, muito da doutrina contemporânea no campo do federalismo econômico está preocupada em desenvolver o equilíbrio ótimo entre competição e cooperação. ${ }^{100} \mathrm{O}$ modelo da União Européia inspira a idéia que um prérequisito para a competição seria o acordo prévio sobre a harmonização essencial a fim de propiciar o "reconhecimento controlado" (managed recognition). ${ }^{101} \mathrm{Na}$ falta desta, o reconhecimento de regimes estrangeiros poderia ficar restrito à escolha de certas jurisdições, ou condicionado a certas exigências de qualidade, de maneira semelhante às normas de

93 Entretanto, hostil à idéia de que a regulação de disclosure de securitização não envolve efeitos a terceiros, Merrit B. Fox, op cit.; Joel P. Trachtman, "Economic Analysis of Prescriptive Jurisdiction ..." O próprio Securities Exchbange.Actprevê que as transações comumente conduzidas nesta área são "afetadas pelo interesse público nacional," enquanto é geralmente tido que o artigo $10 \mathrm{~b}$ foi projetado pata assegurar poder pleno do Securities Exchange Act sobre os mercados (veja Steve Thele, "The Original Conception of Section 10 (b) of the Securities Exchange Act" 42 Stan L Rev 385, 1990),

94 Merrit B. Fox, ibid.

95 Roberta Romano, "Empowering Investors ..." p. 2423, argumentando que não está claro o que disclosure requirements externalities de fato obrigam; compare com Choi \& Guzman, argumentando que a regulação de securitização é baseada na transação. Pode-se também adicionar que grandes bolsas de valores estão crescentemente se baseando em técnicas auto-regulatórias.

96 Veja Moloney, op cit., Capítulo III, demonstrando entretanto que a política de proteção proativa do investidor é algumas vezes preterida por objetivos de integração de mercado dentro da União Européia

9 Ibid.

98 Veja Eleonor Fox, "Antitrust and Regulatory Competition ..."

9) Revesz, op cit.

$100 \mathrm{Ou}$ "coopetição", termo usado para descrever este equilíbrio por Esty e Geradin, op cit.

101 Veja Joel P. Trachtman, "Regulatory Competition ..." 
conflito de leis alternativas ou condicionais. ${ }^{102} \mathrm{Na}$ área de regulação de securitização, a reciprocidade parcial pode também ser uma opção, de acordo com a qual um estado estaria pronto para estender reconhecimento ao regime estrangeiro em certas áreas e não a outras (tal como insider trading), ou a certos tipos de investidores sofisticados. ${ }^{103}$ Duas lições parecem emergir. Primeiramente, a desejabilidade de autonomia da vontade é atribuída aos objetivos e políticas de regulação econômica, ${ }^{104} \mathrm{o}$ que significa que as conclusões irão necessariamente variar. Segundo, os métodos atuais praticados pelas cortes para determinar o alcance da regulação econômica no mercado global são insuficientemente flexíveis; em especial, o rótulo do direito público permanece superinclusivo. Na verdade, o campo da regulação econômica sofre de um rótulo do direito público muito extensivo. ${ }^{105}$ Com base em uma premissa correta, mas de alguma forma indiscriminada, que o direito econômico público envolve interesses governamentais, a prática americana, seguida pela União Européia, ${ }^{106}$ tem tradicionalmente decidido em termos de jurisdição prescritiva em causas de antitruste ${ }^{107}$ e na área de regulação de securitização. ${ }^{108}$ Perante as cortes americanas, as disposições antifraude do Securities Exchange Act têm sido tradicionalmente qualificadas como "direito público". ${ }^{109}$ Entretanto, talvez seja hora de seguir $\odot$ exemplo da jurisprudência, que parece demonstrar uma "mudança na maré". ${ }^{110}$ Tal rótulo quiçá precise ser relaxado, a fim de compreender os objetivos complexos da regulação econômica e identificar as áreas nas quais o foco primário é nos interesses privados ao invés do bem público. ${ }^{111} \mathrm{Um}$ debate emergiu recentemente, no espetacular contencioso Lloyd's, ${ }^{112}$ quando as cortes federais unanimemente mantiveram a autonomia da vontade como relação ao direito e foro inglês, apesar dos efeitos adversos sentidos nos Estados Unidos por investidores que foram induzidos por representantes do

102 Em casos onde o risco de externalidades é particularmente alto, tal como poluição ambiental, os páses destinatários poderiam legitimamente aplicar deveres de compensação. Uma questão difícil então surge acerca dos limites para estas contramedidas: veja Revesz, op cit.

103 Choi \& Guzman, p. 943.

104 Esta é uma questão familiar sob a teoria tradicional do direito internacional privado, de acordo com a qual a escolha do elemento de conexão não deve trair as políticas subjacentes da categoria jurídica relevante. Também explica porque as regras de direito intemacional privado necessariamente variam mundo afora

105 Robert W. Hillman, "Cross-Border Investment, Conflict of Laws, and the Privatization of Securities Law," 1992 Law and Contemporary Problemas, 331, p. 333

106 A jurisprudência da CEJ indica que um raciocínio semelhante em termos de jurisdição prescritiva é adotado no âmbito do antitruste. A regulação européia de securitização ainda está na sua infância, relativamente às questões abordadas pela prática americana assim como ao alcance extraterritorial da regulação de securitização. Sobre a prática dos Estados Membros, veja Kronke, op cit., Capítulo 2).

107 Mais recentemente, em Hartford Fire, 113 S. Ct. 2891 (1993).

108 Veja por exemplo, Zoelsch v. Arthur Andersen, 824 F. 2 d 27 (DC Cir. 1987), rejeitando o caso por falta de competência.

109 Kronke, op cit., p. 272 e nota de rodapé 94, acima.

110 Kronke, p. 276; veja também, Kelly, "Let there be fraud (abroad)," 28 Law \& Policy in Int'l Business 477

111 Hillman, op cit., p 343; compare com Kronke, op cit., p. 298, enfatizando a importância da qualificação funcional das questões regulatórias relevantes. Numa linha similar, Jurgen Basedow, "Souveraineté territoriale et globalisation dês marches ..."

112 Riley v. Kingisey Underwriting Agencies Ltd, 969 F.2d 953 (10th Cir. 1992); Roby v. Corporation of Lloyd's, 996 F.2d 1353 (2d Cr. 1993); Shell v. R.W. Sturge, Ltd, 55 F. 3d 1227 ( $6^{\text {th }}$ Cir. 1995); Allen v. Lloyd's of London, 94 F. $3 d$ d 923 (4th Cir. 1996), Lipcon v. Underwriters at Lloyd's, $148 \mathrm{~F}$ 3d. 1285 ( $11^{\text {th }} \mathrm{Cir}$, 1998); Bonny v. Society of Lloyd's, 3 F 3d $156\left(^{\text {th }} \mathrm{Cir}\right.$. 1993). Veja: Darrell Hall, "No Way Out: An Argument Against Permitting Parties to Opt Out of U.S. Securities Law in International Legal Transactions", Col. L Rev. 1997.57; Courtland H. Peterson, "Choice of Law and Forum Clauses and the Recognition of Foreign Country Judgements Revisited Through the Lloyd's of London Cases," 60 La. L Rev. 1259; Hannah Buxbaum, "The Role of Public Policy in International Contracts: Reflections on the U.S. Litigation Concerning lloyd's of London," Iprax, 2002, no. 3, p. 232. 
Lloyd's para abdicarem suas fortunas pessoais em um nível de disclosure claramente inferior às - aparentemente - exigências dispositivas do artigo 10 b da Lei de Câmbio de Securitização. Quando a corte inglesa decidiu em favor de Lloyd's, o reconhecimento e a execução foram estendidos sem suspeição em nome da ordem pública americana. ${ }^{113}$ Isto não é prova suficiente dos perigos de se relaxar o tabu do direito público ${ }^{114} \mathrm{O}$ resultado foi ainda mais controverso porque as surgiram discrepâncias entre casos de execução de direito público por agências reguladoras, aqueles onde a ação é impetrada por um promotor de justiça privado, e casos em que o direito público é invocado para prevenir a execução de uma cláusula de escolha de lei ou de jurisdição. ${ }^{115}$ Neste último caso, uma importante função de execução parece ter sido abandonada numa corrida regulatório degenerativa para o fundo, em detrimento de interesses públicos americanos previstos em exigências federais dispositivas de disclosure. Lloyd's, já se afirmou, não sobreviverá ao caso Hartford Fire. ${ }^{116}$ Entretanto, também já foi defendido que as decisões Lloyd's podem não ser acidentais. ${ }^{117}$ Diversos precedentes sugeririam que a verdadeira razão em manter a autonomia da vontade reside na natureza privada dos arranjos, negociados livremente e isentos como tais do regime obrigatório de disclosure, ${ }^{118}$ seus efeitos admitidamente nocivos podem ser considerados como preocupantes a investidores privados, e não ao mercado americano como um todo. ${ }^{119}$ Análises recentes sobre a mudança de objetivos da regulação de securitização confere crédito a esta explicação. Parece que as exigências de disclosure do artigo $10 \mathrm{~b}$ podem agora ser justificadas somente por considerações de eficiência, e não pela atenção mais ampliada à proteção do investidor com as quais elas são mais freqüentemente associadas. ${ }^{120} \mathrm{Não}$ existe, então, motivo pelo qual o direito internacional privado não poderia ser chamado a expressar preocupações semelhantes num contexto transnacional, em especial ao permitir autonomia da vontade em transações de boa-fé, assim fomentando a competição regulatória. Por outro lado, onde o bem público está diretamente envolvido, o rótulo do direito público está obviamente justificado e os interesses que este protege deveriam ser representados no contexto internacional. É aqui que o direito internacional privado poderia ser chamado para exercer uma função regulatória significativa.

\section{A função regulatória do direito internacional privado ${ }^{121}$}

Como, então, coordenar a regulação no mercado global e ao mesmo tempo permitir flexibilidade suficiente para acomodar diferentes concepções dó alcance dos direitos nacionais

113 233 F. 3d 473 (7th Cir 2000).

114 McConnaughy, Dodge, op cit

115 Hannah Buxbaum, "The Private Attorney General in a Global Age: Public Interests in Private International Litigation," 26 Yale J Int'l L 219 (2001)

116 McConnaughy, op cit., p. 299.

117 Ktonke op cit., p. 281, argumentando que a mudança da maré já era previsivel em contenciosos envolvendo arranjos privados.

118 Seção 4 (2) Lei de Securitzação. Veja por exemplo, Leasco Data Processing Equipment Corp. v. Maxwell, 468 F. 2d 1326 (2d Cir. 1972);

119 De fato, o direito comparado demonstra que a proteção do investidor pode frequentemente ser tratada através das ferramentas ordinárias do direito-privado.

120 Hillman, op cit., p 344. Logo, a Securities and Exchange Commission (SEC) não mais vê a proteção do investidor como seu objetivo principal (Choi \& Guzman, op cit).

121 Este termo aparece no título de um excelente artigo escrito por Robert Wai, "Transnational Liftoff and Juridical Touchdown: The Regulatory Function of Private International Law in a Era of Globalisation”, 2002 Colum J. Transnat'l L 209. Este foi 
projetados para implementar o bem público? Atualmente, o contencioso envolvendo direito público estrangeiro está sujeito somente a uma abordagem unilateral, monopolista, que visa a garantir que as cortes do foro não servirão a interesses de estados estrangeiros. ${ }^{122}$ Isto é verdade com relação à implementação de regulação econômica estrangeira tanto nos Estados Unidos quanto na União Européia; uma abordagem definida em termos de "jurisdição prescritiva" requer a recusa de uma demanda quando esta não se sujeita ao alcance da legislação federal ou Comunitária, unilateralmente definida - geralmente por referência aos "efeitos" sofridos no mercado nacional. ${ }^{123} \mathrm{Não}$ é nenhum truísmo afirmar que os comportamentos estatais focados neles próprios são dissonantes com a eficiência global ${ }^{124}$ por gerarem inconsistências, ${ }^{125}$ políticas protecionistas agressivas de estados aflitos para protegerem a competência do foro, ${ }^{126}$ duplicação de procedimentos, ${ }^{127}$ custos $^{128}$ e fraude, ${ }^{129}$ em que se exige coordenação internacional. ${ }^{130}$ Evidentemente, ausente um acordo internacional, é improvável haver qualquer solução ideal e certamente nem maiores probabilidades de se alcançar harmonia internacional do que no contexto mais tradicional, menos sensível, dos conflitos em direito privado. ${ }^{131}$ Entretanto, a consciência de que qualquer proposta seja

também o tema da tese de doutorado da presente autora sobre "La Fonction de la Règle de Conflit de Lois," Univ. Paris 2 , em 1985, embora admitidamente a significação de tal termo muito mudou desde então!

12 Sobre a justificação do unilateralismo das abordagens atuais, por referência à idéia que as cortes estatais não são concebidas para serem os instrumentos dos interesses públicos estrangeiros, veja, por exemplo, F. A. Mann, 'L'éxecution internationale dês droits publics," Ver crit DIP 1988.1.

123 Sobre os três testes diferentes (condutas, efeitos e equilíbrio de interesses) que aparecem na prática americana, e sua relação aos testes usados em conflito de leis, veja William Dodge, "Extraterritoriality and Conflict-of-Laws Theory: An Argument for Judicial Unilateralism," 39 Harv. Int'l LJ 101. Enquanto o teste do equilibrio proposto pelo Third Restatement on Foreign Relations, seção 403 (veja Andreas F. Lowenfeld, International Litigation and the Quest for Reasonableness, Claredon Press, Oxford, 1996, em especial capítulos 2 e 3) não foi rejeitado na mais recente decisão da Corte Suprema americana (Hartford Fire, 113 S. Ct. 2891, 1993), resta claro que a maneira em que o teste foi implementado chega muito perto de restabelecer o teste dos efeitos. Este último parece ter sido adotado de fato se não explicitamente pela Corte de Luxembourg no caso Woodpulp (1988, caso 89/85, 1988, RCE 5193)

124 Mas para uma demonstração econômica sofisticada, veja Andrew Guzman, op cit.

125 A dificuldade é bastante familiar: o unilateralismo (inclusive as formas neo-estatutárias tal como a análise dos interesses govemamentais), nunca obteve sucesso em encontrar uma solução satisfatória para as lacunas e sobreposições, conflitos verdadeiros e casos unprovided-for.

126 Onotório contencioso Laker (veja US Court of Appeals District of DC 1984, DC 577 F. Supp. 348; House of Lords 1985, AC 58) é uma demonstração ampla da maneira pela qual a definição unilateral da jurisdição prescritiva cria a necessidade de proteger a jurisdição judicial (através de injunções anti-suit): veja Lowenfeld, op cit.

127 Veja por exemplo, sobre a questão da aventura Boeing/MacDonnell, A Fiebig, "The Extraterritorial Application of European Merger Control Regulation," 5 Colum. J Eur L 79 (1999).

128 A duplicação dos procedimentos de execução obviamente geram altos custos quando a regulação relevante prevê sanções civis e criminais (veja Dorsey Ellis, "Protecting the Long-Arm of the Law: Extraterritorial Criminal Enforcement of US Antitrust Laws in the Global Economy", 1 Wash. Univ. Global Stud L R 477.

120 Veja Emschwiller \& Cooper, "Beyond the SEC's reach: Firms sell Obscure Issues to Foreign Investors" (Wall Street Journal, 16 de agosto de 2000 , enfatizando a extensão pela qual a fraude de securitizações transnacionais é fomentada em razão da confusão sobre a jurisdição regulatória. Joel Trachtman, "Economic Analysis of Prescriptive Jurisdiction and Choice of Law", 42 Va J Int'1 L 1 (2000)

130 Sobre essa necessidade de coordenação, veja, entre muitos outros, Robert Wai, op cit.; W. Kronke, op cit; J. Basedow, op cit; Eleonor Fox, "National Law, Global Markets and Hartfords Fire: Eyes Wide Shut," 68 Antitrust L J 73 (2000); Andréas F. Lowenfeld, International Economic Law, Oxford, 2002, cujo capítulo 12, entitulado "Competition Law" foi contribuído por Eleonor M. Fox

131 Uma notável exceção pode entretanto ser encontrada no ciberespaço, onde o conflito de valores públicos na Internet, tal como a colisão da liberdade de expressão com a proibição de expressão com conteúdo odioso (hate speech) (conforme ilustrado, por exemplo, no recente contencioso Yahoo!) pode ser mais facilmente resolvido do que no mundo real, devido 
apenas uma segunda melhor opção (second best) não deveria deter as tentativas de definir maneiras em que uma estrutura regulatória, embora imperfeita, possa ser alcançada. Efetivamente, a interação entre uma quantidade rapidamente crescente de regulações econômicas nacionais, ${ }^{132}$ provavelmente se tornará o desafio principal para o mercado global nos próximos anos. A verdadeira pergunta é até que ponto as abordagens monopolistas ou puramente "horizontais", ${ }^{133}$ que enfocam no alcance do direito do foro e prestam pouca atenção ao bem-estar global, são inevitáveis. A renovação poderia ser obtida ao reconhecer que a regulação econômica é receptiva à metodologia do direito internacional privado, tradicionalmente restrita ao campo dos interesses privados. Isto implicaria aceitar que as cortes nacionais aplicam direito estrangeiro portando um rótulo "público" (A). Logo, envolveria construir um teste utilizável em que a função mediadora mais tradicional do direito internacional privado também daria espaço para políticas e objetivos ligados ao trabalho harmonioso do mercado global (B).

\subsection{Estendendo o Conflito de Leis aos Conflitos de Interesses Públicos}

\subsubsection{Rompendo o tabu do direito público}

O primeiro passo a ser dado seria enterrar a idéia de que o direito público como tal nunca é receptivo à abordagem do direito intemacional privado porque o direito estrangeiro não é executável perante as cortes nacionais. ${ }^{134}$ Seria obviamente irreal negar a existência de interesses estatais delicados com relação ao resultado de disputas na área da regulação econômica. ${ }^{135}$ Entretanto, não procede a constatação de que tais cortes nacionais nunca deveriam estender suas jurisdições sobre demandas enquadradas como direito público estrangeiro. $\hat{E}$ um paradoxo comparativo estranho que a prática européia continental tenha chegado mais

à possibilidade de usar tecnologia "zoning" para assegurar o cumprimento com um teste de efeitos propriamente calibrado. Sobre a factibilidade deste "zoning" na web, que poderia acarretar "um espaço Coaseano de cumprimento sem custo" numa estrutura global, veja Lawrence Lessig \& Paul Resnick, "Zoning Speech on the Internet: A Legal and Technical Model," 1999 Michigan Law Ver 395; J. Reidenberg, "Yahoo! And Democracy on the Internet," 42 Jurimetrics J. 261.

132 Sobre o crescimento espetacular da regulação nacional de antitruste, com que mais de 80 Estados hoje estão equipados, veja Eleonor M. Fox, "Antitrust and Regulatory Federalism: Races Up, Down and Sideways," NYU L Ver 1781 (2000); uma descrição semelhante aplica-se à regulação do mercado de capitais (veja W. Kronke, op cit., em especial o Capítulo 5). Por exemplo, a organização intergovernamental africana, $\mathrm{OHADA}$, agora tem uma regulação de securitização.

133 Como definido por Eleonor Fox, tal abordagem reconhece os interesses de outros estados somente "num plano nação-paranação, como se o problema fosse que as fronteiras territoriais não tivessem sido suficientemente cuidadas." Conforme ilustrado pela abordagem do Ministro Scalia em Hartford Fire, isto tende a acarretar: "não toque nos meus cartéis de exportação e eu não tocarei nos seus" ... ("National Law, Global Markets ...", p. 81).

134 O "direito público como tal" cobre pretensões baseadas diretamente em direito público, tal como uma pretensão baseada na violação de legislação antitruste, ao contrário da aplicação incidental de direito público estrangeiro, seja como parte da lei que regula o contrato ou como dado. Sobre a distinção, veja Hans Baade, op cit.

135 A prática das cortes revela tentativas curiosas de negar a presença de interesse estatal (contraste, no contencioso Laker, as observações do Lord Diplock, para quem o contencioso estava dentro do âmbito do direito privado, veja $1985 \mathrm{AC}$. 85 , com a análise do juiz americano Wilkey, que viu "na raiz um claro confronto de políticas governamentais," 731 F 2d 909, p. 955). Foi demonstrado muito convincentemente que a referência à cortesia internacional, recorrente nesta e em contenciosos semelhantes, pode funcionar alternativamente como uma ponte ou uma parede entre direito privado e política: Joel R. Paul, "Comity in International Law", Harv. Int'l L J 1991. 1. Sobre a relação, mais geral entre o judiciário e política externa, a partir de uma perspectiva inglesa, L. Collins, "Foreign Relations and the Judiciary," International and Comparative Law Quarterly (2002) 485 . 
perto deste resultado do que sua contraparte americana, apesar da ligação muito mais forte dessa última com o paradigma do interesse privado em direito internacional privado. ${ }^{136}$ Entretanto, quaisquer que sejam as diferenças mundo afora, as razões para que o tabu do direito público pareça fadado a desaparecer são claramente universais. As mudanças parecem tão inevitáveis hoje quanto, há um século atrás, a aceitação gradual pelas cortes ainda trabalhando sob concepções territoriais, de que elas poderiam ignorar o "tabu do direito público" e aplicar o direito de outras jurisdições como tais. ${ }^{137}$ Agora, assim como antes, dois tipos de entendimentos justificam relaxar qualquer abordagem exclusiva. ${ }^{138}$

\subsubsection{As implicações normativas da globalização}

O primeiro está ligado ao postulado que se situa no coração do "paradigma do poder" subjacente à perspectiva da jurisdição prescritiva, e concebe o estado como uma cidadela regulatória. ${ }^{139}$ Tal visão monopolista é dificilmente sustentável em um contexto

136 Curiosamente, a prática européia atualmente está muito mais próxima deste resultado do que estão as cortes americanas e a academia, embora aquela tenha tradicionalmente se oposto a qualquer sugestão que o direito intemacional privado deveria se preocupar com interesses estatais. Significativamente, quando Gerhard Kegel lidou com o que geralmente é tido como a última gota à potencial influência de Currie na Europa ("The Crisis of the Conflict of Laws," Rec Cours Acad. La Haye, 1964-II, t. 112, p. 91, e veja parágrafo primeiro deste artigo, acima, e nota de rodapé 10), ele o fez precisamente através da demonstração de que o direito internacional privado não envolve políticas governamentais, ou, para colocar a mesma idéia diferentemente, que os governos não estão interessados no resultado de contenciosos de direito privado. Efetivamente, no período pós-guerra mundial tomou-se crescentemente aparente que as regulações econômicas intemacionalmente imperativas frequientemente interferiam com a liberdade de escolha das partes sobre a lei aplicável, tentativas de teorizar o seu impacto (teoria inicial de "Sonderanknufung" desenvolvida entre as duas guerras mundiais por Wengler e Zweigert no Instituto Kaiser Wilhelm; a posterior teoria da "lois de police" desenvolvida na França por Franceskakis no início dos anos 60 ) a regulação econômica intemacionalmente imperativa parecer como uma exceção unilateral ao princípio metodológico getal da multilateralismo. Enquanto mantém o seu status excepcional em relação ao princípio da autonomia da vontade, o artigo 7 inciso $1 \mathrm{da}$ Convenção de Roma sobre o Direito Aplicável às Obrigações Contratuais estipularia especificamente que as disposições imperativas de um terceiro estado que pretende regular uma certa transação qualquer que seja a lei escolhida pelas partes, podem ser aplicadas pela corte do foro quando apropriado. Logo, sem estender um tratamento comum aos conflitos de interesses públicos e privados, esta importante disposição pareceria dispensar obstáculos jurisdicionais para a execução de direito público estrangeiro relevante para a disputa contratual. Esforços tem desde então sido direcionados ao refinamento da análise dos diferentes tipos de disposições imperativas enquadradas no artigo 7. Admitidamente, esta disposição tem sido apenas relativamente exitosa em generalizar a aplicação incidental de direito público estrangeiro: Alemanha e Reino Unido a rejeitaram, e aplicações concretas permanecem decididamente evasivas. Ademais, quando a CEJ foi acionada para definir o alcance da regulação econômica Comunitária, ela adotou uma abordagem enquadrada em termos de jurisdição prescritiva, que leva à rejeição de qualquer pretensão não appiada pelo direito do foro. A cena americana, que há tempo é favorável às análises políticas do direito intemacional privado, parece oferecer uma estrutura mais auspiciosa para uma teoria do conflito de regulação econômica. Entretanto, fora do contexto interestadual, que claramente absorveu a energia dos acadêmicos do direito internacional privado, o paradigma do poder inerente à tradição da common lau tem persistido, e tem levado a lidar com o alcance intemacional da regulação econômica federal em termos de "cjurisdição prescritiva." Esta abordagem tem sido agregada à questão da coinpetência das cortes federais: se não há uma questão federal, então as cortes federais competência para decidir a disputa

137 Isto é, sem a intermediação dos direitos adquiridos ou outras doutrinas semelhantes (tal como a teoria italiana da recepção do direito estrangeiro) criadas para burlar a tida impossibilidade para as cortes do foro em aplicar direito estrangeiro como tal.

138 A multiplicação de relações privadas internacionais, devido em especial à nova facilidade de transporte e comunicação, era vista como tendo implicaçôes normativas para os estados, que não mais podiam ignorar o direito estrangeiro sem injustiça aos litigantes privados. Ao mesmo tempo, as instituições estrangeiras foram invocadas como a base de pretensões perante as cortes do foro, que deviam portanto referir-se àquelas, por uma questão prática. Ambas as considerações normativa e pragmática igualmente aplicam-se hoje até onde o tabu do direito público está envolvido.

139 Sob a abordagem da jurisdição prescritiva, a autoridade regulatória é uma expressão do poder do estado, para ser alocado como tal, porquanto o paradigma do direito privado vê a aplicação do direito estrangeiro como uma questão de justiça privada e conveniência. 
global; os mercados interconectados claramente requerem uma estrutura verdadeiramente internacional. ${ }^{140}$ As fronteiras territoriais não são mais (se é que elas um dia foram) uma barreira contra os efeitos econômicos de atividades oriundas de outras jurisdições. ${ }^{141} \mathrm{~A}$ interdependência econômica entre mercados nacionais assim se torna um argumento normativo em favor do dever de cada legislador de contribuir para a regulação global. ${ }^{142} \mathrm{O}$ professor Robert Hillman argumenta que ao abrirem os seus mercados, os Estados na verdade renunciam à pretensão de competência regulatória exclusiva sobre transações transfronteiriças. ${ }^{143}$ Indícios do elo entre as mudanças econômicas globais e a conseqüente necessidade de coordenação no campo da regulação econômica podem ser encontrados na prática judicial comparada. Por exemplo, a Corte Federal Suíça sustentou que à luz da crescente internacionalização dos mercados de capitais, estender assistência espontânea a autoridades estrangeiras é desejável para os próprios interesses nacionais suíços, ${ }^{144}$ enquanto a recente codificação suíça de direito intemacional privado prevê uma norma multilateral no campo da responsabilidade extracontratual oriunda de práticas antitruste. ${ }^{145}$ Esses indícios são alargados pelo fato de que os testes utilizados para definir a jurisdição prescritiva são com freqüência praticamente permutáveis com àqueles reconhecidos dentro do direito internacional privado. ${ }^{146}$ Por exemplo, enquanto a regra da razão implementada no Third Restatement on Foreign Relations Law dos Estados Unidos (Seção 403) levará apenas à decisão de não aplicar o direito do foro se os interesses envolvidos não pesarem em favor de sua aplicação, todavia, tal teste sugere uma prontidão em contemplar interesses públicos estrangeiros de forma similar à abordagem da "relação significativa" (significant relation) do Second Restatement on the Conflict of Laws. ${ }^{147}$ Efetivamente, parece que a idéia tradicional, famosamente enunciada pelo Lord Wilberforce no caso Westinghouse, de acordo com a qual dar efeito ao direito público estrangeiro

140 Kronke, p. 288; Eleonor M. Fox, "National Law, Global Markets and Hartford Fire: Eyes Wide Shut," 68 Antitrust LJ 73 (2000).

141 Veja Kenichi Ohmae, “The Borderless Worlds, 1990:" Num mapa politico, as fronteiras entre os países estão tão claras como sempre. Mas um mapa competitivo, um mapa mostrando os verdadeiros fluxos de atividades financeiras e industriais, aquelas fronteiras amplamente desapareceram." (p. 10)

142 Veja J. Basedow, "Souveraineté territoriale et globalisation des marches," Rec Cours Acad La Haye t. 264, p. 9 (1997).

143 Robert W. Hillman, "Cross-Border Investment, Conflict of Laws, and the Privatization of Securities Law," 1992 Law and Contemporary Problemas 331; para uma idéia semelhante, op cit., p. 285.

144 Várias decisões exaradas em 1998 (veja BG 125, I, p. 65 e p. 79), estenderam a cooperação para agências regulatórias estrangeiras, tal como o Hong Kong Securities amd Futures Commission, e a Comissão Nacional de Mercado de Valores (Espanha). Veja Kronke, op cit., p. 270. A interconectividade pode agora ser suficientemente estabelecida para contrapor o risco de gerar a dinâmica do dilema do prisioneiro. Outro interessante exemplo de prontidão para adotar metodologias mais abertas sob a pressão da globalização é o exemplo da Suprema Corte do Canadá no caso Morguard Investment de 1990 (3 SCR 1077 Can). Várias situações podem ser encontradas em que as cortes prontas para executar decisões estrangeiras exaradas com base em legislação pública híbrida em questões ambientais (veja sobre este ponto Robert Wai, op cit., e o texto acompanhando a nota de rodapé 203).

145 Artigo 137 da lei suiça de direito internacional privado. Sob esta disposição, as cortes suíças decidirão uma pretensão de compensação com base na conduta exclusiva no mercado americano, mas não disponibilizará reparação (tal como perdas e danos punitivos) não disponivel na lei suíça (veja Basedow, op cit., p. 440).

146 Veja Dodge, op cit.

147 Tal é verdade com relação ao teste dos efeitos, à medida que interesses estrangeiros podem ser considerados em casos de verdadeiro conflito. Embora, admitidamente, os efeitos da jurisdição permaneçam concorrentes, uma forma mínima de comparação pode ser exigida se os efeitos fotem classificados como substanciais a fim de justificar a jurisdição prescritiva. 
necessariamente implica em executar interesses hostis estrangeiros, ${ }^{148}$ está em declínio ${ }^{149}$ na verdade, pode bem ser que a regulação na área da securitização, antitruste, meio ambiente ou proteção do patrimônio cultural enquadre-se dentro de categorias em que interesses "típicos" possam ser identificados como um pré-requisito necessário à coordenação. ${ }^{150}$ Entretanto, recentes manifestações nos Estados Unidos para o revival do tabu do direito público ${ }^{151}$ claramente baseiam-se no distinto temor de que introduzir o conflito de leis levará à subordinação do bem público a esquemas puramente privados, ao invés de interesses estrangeiros. Esses temores estão inteiramente fora de contexto. Eles surgem muitas vezes de reações aos resultados atingidos no recente contencioso Lloyd's, ${ }^{152}$ em que os particulares estariam sendo permitidos a abdicarem do direito público federal. Contudo, como nós vimos, tal rótulo era provavelmente inapropriado desde o princípio. Todavia, nos campos em que os interesses públicos autenticamente clamam por proteção, talvez seja hora de abandonar a idéia de que seria necessariamente contrário aos interesses do foro do estado servir aos objetivos soberanos estrangeiros ao aplicar o seu direito público. ${ }^{153}$

\subsubsection{Mistura de interesses, de fato}

Mais pragmaticamente, a conclusão de que o direito público poderia sujeitar-se à metodologia do conflito de leis está relacionada com a mistura de interesses privados e públicos que já existe na prática e que torna toda tentativa de excluir os últimos do direito internacional privado muito difícil. De fato, um breve exame na jurisprudência recente em várias jurisdições aponta para tais mudanças nas categorias como a dificuldade chave encontrada na filosofia e prática contemporâneas nesta área. Nos Estados Unidos - agora a ser seguido pela União Européia ${ }^{154}$ - o surgimento do promotor de justiça privado ${ }^{155}$ e outros indicadores ${ }^{156}$ em contenciosos transnacionais significam que as disputas entre litigantes privados podem bem envolver a execução de interesses regulatórios públicos. ${ }^{157}$ Interesses

148 "É axiomático que em questões de concorrência, a política de um estado possa ser a de se defender contra a política de ataquue de outro Estado" (1978 AC p. 616-17). Esta posição é justificada por um número considerável de conflitos transatlânticos, que tem levado a um envolvimento judicial agressivo, em especial através do uso de injunções anti-suit, com vistas a proteger a jurisdição prescritiva. Enquanto a natureza política desses conflitos é inegável, uma visão mais esclarecida pode ser de quue a não-aplicação do direito público estrangeiro, em casos onde a sua implementação é necessária para concretizar uma política estatal forte, é que seria considerada hostil (veja P. Mayer, "Les lois de polices étrangères," JDI 1981.277).

149 Veja a Resolução Oslo do Instituto de Direito Internacional, 1975, Annuaire, vol. 57 t. II, p. 2 e p. 166.

150 Kronke, op cit., p. 288.

151 Philip J. McConnaughy "Reviving the Public Law Taboo in International Conflict of Laws," 35 Stan. J. Int'1 L. 255; Dodge, op cit.

152 Veja acima, nota de rodapé 113

153 Veja a impressionante relação de acordos da OMC incluindo referências ao direito da concorrência descrita por Eleonor M. Fox, "Antitrust and Regulatory Competition ..." p. 1787.

154 A P Kominos, "The Prospects for Private Enforcement of EC Community Law: Courage v Crehan and the Community Rights to Damages," 39 Common Market Law Rev 447-487, e o Livro Branco da Comissão para a modemnização do direito da concorrência da CE, Prog. Com. N0.99/027, Com (99) 101, OJ 1999, C 132/1.

155 Sobre as dificuldades levantadas pelo promotor de justiça privado em contenciosos intemacionais, veja Hannah Buxbaum, "The Private Attorney General in a Global Age: Public Interests in Private International Litigation," 26 Yale J Int"l L 219(2000); Howard M. Erichson, "Coattail Class Actions: Reflections on Microsoft, Tobacco and the Mixing of Public and Private Lawyering," 34 UCDavis LR1 (2000).

156 Veja Alan Riley, "Cartel Whistle-blowing: Towards an American Model?," 9 Maastricht Journal 1 (2002).

157 Novamente, a notório contencioso Laker é um excelente exemplo (veja acima, nota de rodapé 127). 
públicos aparecem proeminentemente, também, em questões de jurisdição judicial portando um rótulo de direito privado, como o uso de forum non conveniens na área de responsabilidade pelo produto, onde ações coletivas com autores estrangeiros bem podem ser rejeitadas por razões ligadas aos custos de administração da justiça — ou, mais controversamente, à proteção da indústria americana no estrangeiro. ${ }^{158}$ Nos países europeus, teorias neo-estatutárias estão ganhando novo espaço com abordagens baseadas em direitos fundamentais, que ao criarem direitos de ação tanto contra outros cidadãos quanto contra o estado, tornam nebulosa a separação entre as esferas política e jurídica. É também aparente que a mudança da relação entre os interesses estaduais e individuais não é uma via de mão única. Políticas regulatórias econômicas não são monopólio do direito público. ${ }^{159} \mathrm{Em}$ ambos os lados do Atlântico, a extensão do alcance da arbitragem para áreas previamente cobertas pela jurisdição exclusiva de cortes estatais ${ }^{160} \mathrm{e}$ a tendência de descentralizar procedimentos de execução ${ }^{161}$ contribuem para a incerteza generalizada com relação a onde colocar a linha divisora entre direito público e privado e, talvez para a indagação se ainda é necessário fazê-lo, do ponto de vista do conflito de leis. Se, então, admite-se que as razões que justificam o tabu do direito público não são mais convincentes como outrora, a próxima questão é como melhor coordenar aquelas regras que expressam políticas econômicas regulatórias.

\subsection{Coordenando regulações conflitantes}

\subsubsection{Foco no bem-estar global}

A doutrina recente convida a considerar uma visão mundial da regulação econômica, ${ }^{162}$ superando uma perspectiva "horizontal", ${ }^{163}$ para abarcar uma concepção "cosmopolita" de governança transnacional. ${ }^{164} \mathrm{Em}$ tal perspectiva, de acordo com a qual o "nosso velho

158 Sobre o foreign non conveniens como uma ferramenta regulatória, veja R. Weintraub, "When and How to Demagnetise Magnet Fonums," 12 Kings College LJ 195 (2001).

159 Veja o texto do primeiro parágrafo deste artigo.

160 A tendência foi instituída pela decisão Misubishi da Suprema Corte dos Estados Unidos (105 S. Ct. 3346)

161 Boundenbacher \& Higgins, "Decentralization of EC Competition Law. Enforcement and Arbitration," 8 Colum. J. Eur. L. 1

162 A literatura é abundante. Veja, por exemplo Eleonor Fox, "National Law, Global Markets ...;" também, as excelentes contribuições, focando nas externalidades da globalização: "The New Movements in International Economic Law (Interdisciplinary Approaches to International Economic Law); American Joumal of Law and Policy (1995), com observações introdutórias de Joel Paul sobre "Sovereignty and the Market". Igualment, "Antitrust Goes Global," resenha de livro, 8 Colum. J Eur L 141. Russel Weintraub, "Extraterritorial Application of Antitrust and Securities Laws. Na Inquiry into the Utility of a Choice of Law Approach," 70 Tex Law Ver 1799

163 Eleonor Fox, "National Law, Global Markets ..." Porque um dilema do prisioneiro é desencadeado entretanto quando as cortes imitam acordos globais hipotéticos, a autora enseja que "paises responsáveis" tomem a dianteira nesta nova abordagem, talvez sob os auspícios da OMC.

164 Robert Wai, op cit. Pode bem ser que tal concepção requeira muito mais do que uma abordagem de direito internacional privado possa efetivamente oferecer. Dentro da União Européia, foi sugerido, muito convincentemente, que a comitologia (comitology) pode ser a melhor - e talvez a única - resposta aos verdadeiros casos de direito internacional privado (veja as inovadoras publicações de Christian Joerges sobre esta questão, tal como "Law, Science and the Management of Risks to Health at the National, European and International Level - Stories on Baby Dummies, Mad Cows and Hormones in Beef," 7 Colum. Journ. Eur Law 1 (2001); Christian Joerges \& Jurgen Neyer, "From Intergovernamental Bargaining to Deliberative Political Processes: The Constitutionalization of Comitology," 3 European Law Journal, 273-299 (1997); "The Law's Problems with Governance of the European Market," in Good Governance in Europe's Integrated Market, ed. Christian Joerges \& Renaud Dehousse, Oxford, 2002 
paradigma do Estado-Nação não é mais suficiente para a tarefa", ${ }^{165}$ o desafio é ver como o direito internacional privado poderia melhor servir não meramente ao bem público assim visto através das lentes nacionais, mas os requisitos de bem-estar global. Para fazê-lo, deverse-ia enfocar em priorizar uma estrutura neutra para coordenação ao invés da implementação de interesses estatais específicos (a). Lições tanto do direito internacional tradicional quando de abordagens do tipo de interesses governamentais parecem indicar que o teste dos "efeitos" faz mais sentido tanto em termos políticos ${ }^{166}$ quanto econômicos. ${ }^{167}$ Entretanto, claramente requer-se maior determinabilidade, que poderia ser atingida incrementalmente ao construir princípios de preferência a partir do campo do estudo comparativo (b).

\subsubsection{Bem-estar global como coordenação}

Obviamente, problemas de definição surgem neste momento. Pode de fato haver um debate com relação ao instrumento de medida para mensurar o bem-estar global. ${ }^{168} \mathrm{~A}$ recente análise econômica do direito enfocando na escolha do instrumento de medida tem reforçado os valores individuais tal como a proteção das expectativas das partes, redução dos custos da informação jurídica e evitar o forum shopping como os objetivos apropriados do conflito de leis, ao invés da promoção de interesses governamentais. ${ }^{169}$ Tal posicionamento dificilmente surpreende o observador europeu, onde a "justiça do direito internacional privado" (conflicts justice) tem sempre servido a esses interesses, pelo menos em áreas tradicionais. ${ }^{170}$ Dois problemas surgem com esse ponto de vista, entretanto. Por um lado, é inegável que no campo do direito público, regulações econômicas estatais obrigatórias expressam várias concepções de bem público, cuja implementação pode oprimir considerações

165 Eleonor M. Fox, "National Law, Global Markets ..." p. 73; veja, também, J. Trachtman, "L'Etat, C'est Nous: Sovereignty, Economic Integration and Subsidiarity," 33 Harv. Int'l L J 459 (1992). Compare, de uma perspective de direito internacional público, H. Ruiz-Fabri, "Immatériel, territorialité et Etat", 43 Archives de Philo. Du Droit, 187 (1999).

166 Por exemplo, o boicote secundário imposto extraterritorialmente pelos Estados Unidos sob a Lei Helms-Burton é considerado como um exercício ilegal de jurisdição prescritiva à medida que ele não tem nenhum embasamento sob a doutrina dos efeitos: veja Lowenfeld, "Congress and Cuba: The Helms-Burton Act", 90 Am J Intl L 419; Fidler, "Libertad v. Liberalism: An Analysis of the Helms-Burton Act from within the Liberal International Relations Theory, 4 IJGLS 297.

16 Erin O'Hara \& Larry E. Ribstein, "Second Generation Law and Economics of Conflict of Laws: Baxter's Comparative Imairment and Beyond," 51 Stan L Rev 1011 (1999); Joel Trachtman, "Conflicts of Laws and Accuracy in the Allocation of Governmental Responsibility," 26 Vand. J. Transat. L 975 (1994), observando que a a teoria dos direitos negativos de Lea Brilmayer é uma expressão em termos econômicos do conceito de externalização; pelo mesmo autor, "Economic Analysis of Prescriptive Jurisdiction and Choice of Law," $42 \mathrm{Va} \mathrm{J} \mathrm{Int'l} \mathrm{L} 1$ (2000). Entretanto, veja Guzman, op cit,, demonstrando que a doutrina dos efeitos não garante um alinhamento dos incentivos do legislador local sobre os interesses da comunidade global. Embora isto possa ser verdade, o instrumento de medida do bem-estar global proposto por este autor descarta a questão distributiva que é possivelmente o coração do direito internacional privado. Implantar uma fábrica que polui o meio ambiente no estado $A$, de acordo com o critério global de Guzman, poderia ser globalmente desejável se os danos sentidos no Estado A forem minimizados por um aumento de lucros gerado para o produtor no estado B. Entretanto, a pretensão do estado A de regular esta questão restritivamente, sob o teste dos efeitos, dificilmente pode ser vista como ilegítima. $O$ teste dos efeitos impede as questões distributivas de serem ignoradas e portanto garante a expressão das preferências locais.

108 Chamando atenção para esta questão, Paul B. Stefan, "The Political Economy ..." p. 957

169 Por exemplo Erin O'Hara \& Larry Ribstein, "From Politics to Efficiency in the Choice of Law", 67 U Chi L R 1151 (2000); Michael Whincop e Mary Keyes, "Towards an Economic Theory of Private International Law", 25 Austr. J. Legal Philosophy 1 (2000); Guzman, op cit.

170 Veja G. Kegel, op cit:; também Jan Kropholler e Jan von Hein, "From Approach to Rule Orientation in American Tort Conflicts?" in Law and Justice in a Multistate World, Essays in Honor of Arthur von Mehrer, Transnational, 2002, p. 317, p. 339. 
de justiça privada e conveniência. ${ }^{171}$ Por outro lado, a busca do bem-estar global não pode significar dar uma expressão coletiva para certos valores substantivos, como a proteção do investidor ou competição livre, pois as políticas do estado por trás da regulação econômica são inevitavelmente divergentes. ${ }^{172} \mathrm{Em}$ termos práticos, esta dupla restrição somente pode significar que se o direito internacional privado deve sobrepor-se a abordagens provincianas ou "horizontais", ${ }^{173}$ sua contribuição ao bem-estar global deve residir exclusivamente em uma coordenação ótima das expressões divergentes de autoridades regulatórias, ${ }^{174}$ impulsionada nada mais do que para evitar sub- e super-regulação em casos de externalidades transfronteiriças e erradicação de discriminação. ${ }^{175} \mathrm{O}$ direito internacional privado recuperaria sua "neutralidade" perdida neste tocante, ${ }^{176}$ e os objetivos tradicionais um tanto obscuros tal como o "funcionamento sereno do sistema internacional"177 ou a "coordenação de sistemas" 178 poderiam encontrar um significado renovado. Neste respeito, sugeriu-se, recentemente, que a prática nacional estendendo o alcance de acordos jurisdicionais e cláusulas de arbitragem para áreas previamente reservadas à jurisdição exclusiva de cortes nacionais, e correlativamente o reconhecimento deliberado de decisões estrangeiras ou laudos de arbitragem dentro de tais campos na arena internacional, está trazendo uma mitigação gradual ao unilateralismo estatal; normas internacionais de aplicação imediata são agora, na maior parte dos casos, apenas "semi-dispositivas", porquanto a sua presença não é mais um obstáculo à livre circulação de decisões e laudos estrangeiros que não necessariamente cumprem com os seus requisitos. ${ }^{179}$ A execução da decisão inglesa no contencioso Lloyd's surge neste contexto como um excelente exemplo de auto-disciplina judicial no contexto internacional, induzida pela interconexão dos mercados globais. ${ }^{180}$

171 Esta é uma das razões pela qual a criação de ações privadas para executar direito público econômico pode não ser uma solução ótima. Incentivos privados não necessariamente otimizam o bem-estar global: veja Paul B. Stefan, "The Political Economy ...," p. 986.

172 D agama de políticas potencialmente diferentes por trás da regulação de concorrência, veja Eleonor Fox, "Antitrust and Regulatory Federalism ..."

173 Eleonor Fox, "National Law, Global Markets ...," p. 84.

174 A "mera" coordenação é uma tarefa enganosamente ambiciosa. Além da impossibilidade, descrita acima, de descobrir políticas compartilhadas universalmenté, é a natureza complexa da regulação econômica, que demanda várias fontes e instrumentos diferentes (inclusive agèncias regulatórias) que a teoria clássica não imaginou. Veja sobre este ponto Kronke, op cit., p. 291, enfatizando que os riscos de inconsistência são maiores quanto mais heterogêneos e "incomuns" forem as ferramentas de reguiação

175 Para tomar um exemplo da prática americana, um Estado que impõe sanções penais sobre empresas estrangeiras por engajaremse em cartéis de exportação não pode esperar deferência internacional com relação as suas próprias políticas eximindo empresas nacionais de uma conduta semelhante. $O$ Webb-Pomenene Act, 1918, prevê uma dispensa para cartéis de exportação, que foi ampliada pelo Export Trading Act, 1982

176 Veja acima. Sobre o conceito de "eficiência do direito internacional privado" ao contrário da "eficiência substantiva," veja Trachtman, "Economic Analysis of Prescriptive Jurisdiction ...". É certamente interessante que um autor americano esteja propondo uma distinção semelhante, central à tradição européia (veja G. Kegel, op cit), que existe uma diferença entre direito internacional privado e justiça substantiva!

17 US Restatement 2nd of the Conflict of Laws, seção 6, d, p. 13 (1971).

178 Batiffol, Aspect philosophiques du droit international privé, 1957.

179 L. Radicati di Brozolo, «Mondialisation, juridiction, arbitrage: vers dês règles d'application semi-nécessaire ? " Rev crit DIP 2003.1.

180 Sobre o impacto da giobalização no contexto da contencioso Lloyd's, veja Horatia Muir Watt, "L'affaire Lloyd's: giobalisation dês marches et contentieux contractuel", Ver crit DIP 2002.508. 


\subsubsection{Princípios de preferência}

Alguém pode portanto ficar tentado a formular um simples teste de "efeitos" multilaterais, no qual a autoridade legislativa seria atribuída à comunidade sofrendo os efeitos adversos mais extensos de uma dada atividade, e portanto com o maior incentivo de regula-la otimamente. ${ }^{181}$ Entretanto, muito embora tal idéia seja certamente plausível, é também um tanto simplista, assim expressa, e requereria enfrentar o problema da indeterminabilidade. ${ }^{182}$ De fato, onde os efeitos são muito difundidos, a difícil questão de pretensões regulatórias concorrentes deve ser endereçada; pode até ser necessário dispersar a jurisdição em tal caso. ${ }^{183}$ Similarmente, quando a proteção do mercado nacional não é o foco de uma dada legislação estatal, faz pouco sentido aplicar sua legislação com base somente no teste dos efeitos. ${ }^{184}$ Seria necessário refinar a regra. Princípios de preferência construídos com base em análise cuidadosa acerca da natureza e fonte das extemalidades com as quais as legislações conflitantes buscam lidar pode ajudar a fornecer orientação em casos de interesses concorrentes; estudos de campo comparados poderiam contribuir, neste sentido, para a elaboração de elementos de conexão tidos como os mais largamente aceitos, ${ }^{185}$ enquanto o conteúdo de acordos bilaterais já alcançados deveria ser levados em conta. Assim, usando o exemplo do antitruste, Eleonor Fox sugeriu que quando os efeitos estão circunscritos ao próprio Estado, ${ }^{186}$ parece legítimo deixar-se regular soberanamente; por outro lado, quando há respingos ou "efeitos ondulados" (ripple effects) de condutas essencialmente projetadas a responderem às condições no mercado nacional, ${ }^{187}$ a regulação ficaria mais bem deixada para o país destinatário, que teria maior incentivo para internalizar os efeitos anticompetitivos da conduta. Quando o foco da legislação nacional não é o mercado, mas atores individuais, o maligno princípio do reenvio pode ajudar a alcançar a coordenação ótima. ${ }^{188}$

\section{Conclusão: mercados globais e universalismo}

Pode bem parecer ingênuo desejar soluções para os conflitos de regulações econômicas globalmente aceitas, "universais", como se as prévias mudadas de direção da roda metodológica não tenham ensinado nenhuma lição. De fato, no campo do direito privado, esforços prévios

181 Sobre esta idéia, veja os autores citados na nota de rodapé 179, acima.

182 Veja Paul Stefan, "The Political Economy ...," p. 964

183 Sobre esta questão, veja Joel Trachtman, "Economic Analysis of Prescriptive Jursdiction ...," apontando que tal solução não seria normalmente atingida através de um simples teste de dano concorrente (comparatize impaimment).

184 Sobre a inadequação do mercado afetado como o elemento de conexão exclusivo, veja Kronke, op cit., p. 291 , p. 368.

185 O estudo comparativo de Herbert Kronke da prática no âmbito da regulação de securitização é uma excelente ilustração do tipo de análise que se poderia adotar. Veja em especial as muito detalhadas sugestões oferecidas no capítulo III do seu curso de Haia.

186 Tal como nos casos Woodpulp ou Hartford Fire

187 Tal como no caso Nippon Papex (109 F. 3d 1; sobre este caso como um "relato de advertência," em vista das sanções criminais também presentes em caso de uma violação concorrencial, veja Dorsey D. Ellis, op cit., p. 492).

188 Joel Trachtman desenvolve o conceito de "hegemonia contingente", de acordo com a qual o govemo mais interessado cuja autotidade regulatória é primordialmente alocada poderia então dispersar esta alocação e, sujeito à taxa da agência, delegar para outros reguladores. O bom e velho reenvio está decididamente renovadol Ele é de fato reinserido em novos contextos periodicamente (veja Larry Kramer, "Return of the renvoi", 66 NYULR 979 1991; Adrian Briggs, "In Praise and Defense of Renvoi," 199847 ICLQ 877; Paolo Picone, "La méthode de référence à l'ordre juridique compétent du for en droit intemational prive," Rec Acad. La Haye 1986.II, p. 229). 
para apresentarem o direito internacional privado como "neutro" não têm sido bemsucedidos, enquanto análises de interesses governamentais, que podem parecer mais apropriadas no campo dos conflitos de direito público, carrega o duplo estigma de discriminação ou lex forismo. Mas pode ser que por mais divergentes que as políticas regulatórias possam ser, uma necessidade compartilhada de participação no mercado mundial cria bases comuns suficientes entre os direitos econômicos estaduais para que uma abordagem global seja sustentável. Baseada na coordenação, tal abordagem teria a dupla vantagem de ser aplicada por árbitros internacionais, cada vez mais chamados a participarem no trabalho sereno do mercado global, e de melhorar a responsabilização das agências regulatórias. ${ }^{189}$ Tomar a dianteira das mudanças que já acontecem na própria União Européia, o preço a ser pago pela teoria jurídica Européia ${ }^{190}$ seria de aceitar o direito internacional privado como uma ferramenta de economia política.

189 Clamando por tal responsabilização, Anne-Matie Slaughter, "The accountability of Governmental Networks", 8 Indiana Journal of Global Studies 347 (2000).

190 Como o artigo de Joel R. Paul sobre "Comity in Intemational Law" (1991 Harv Int'l LJ 1) demonstra, a verdadeira contribusção da interdisciplinaridade acadêmica americana para esta área tem sido em enfatizar a importância do contexto. $O$ conflito de leis pode então ser investido de funções econômicas e políticas que estão muito além da estaca do paradigma do direito privado. 